https://doi.org/10.7592/TF11.jaagod

\title{
Välitööd: Maidla näide
}

\author{
Kalev Jaago, Tiiu Jaago
}

Teesid: Artiklis vaadeldakse välitöö kui ühe andmekogumise meetodi kujunemist 20. sajandi lõpul, mil välitööd lülitusid taas üha enam interdistsiplinaarsesse ja kvalitatiivsesse uurimispilti. Maidlas 1987. aastast alates toimunud välitööde näitel arutletakse selle üle, mis eesmärkidel kohalikke inimesi küsitleti ja mil viisil kuuldut dokumenteeriti. Võrreldakse arheoloogiliste kaevamiste juurde kuulunud külaelanike küsitlusi folkloristlikul välitööl tehtuga. Näidatakse, kuidas uurimisprotsessis kujundatakse vaadeldavat piirkonda puudutav mitmekihiline materjalikogu, kus välitöö põimub muude uurimismeetoditega, sh arhiivitööga. Mida enam põimub välitöö uurimisprotsessi teiste osadega, seda keerulisemaks muutub välitööandmete koondamine ja üleandmine kesksesse arhiivi. Ühtlasi pakub artikkel ühe võimaliku sissevaate Maidla pere- ja kohaajaloosse.

Märksõnad: “eesti aeg”, Ilmar Jõesoo, koha- ja pereajalugu, Maidla, välitöö

Folkloristlike välitööde üks eesmärke on vaadelda rahvaluulet selle ühes ja ainulaadses kontekstis - pärimuskeskkonnas (kõrvutatuna näiteks arhiivi-, kooliõpetuse vms kontekstiga). Ajalooliselt on välitööd pakkunud ühe võimaluse (näiteks vabatahtlike kirjasaatjate kaastööde kogumise kõrval) dokumenteerida rahvaluulet, et luua uurimiseks vajalik allikmaterjal - arhiiv. Kuid teisalt võib arhiivi põhjal tehtud uurimus suunata uurija omakorda välitöödele lisaandmeid koguma. Vaadatagu kasvõi näiteks Ülo Tedre uuema rahvalaulu käsitlust, kus autor läheb laulus jutustatava sündmuse ajaloolise 
tausta mõistmiseks lisateavet otsima välitöödele Kanepisse (Tedre 2003, 119-120). Välitöö kui rahvaluule talletamise üks meetodeid on samal ajal läbi põimunud uurimisprotsessi teiste tööetappidega ega eristugi alati selgepiiriliselt materjali korrastamisest või selle kasutamisest uurimuses.

Folkloristlikele välitöödele on suhteliselt lähedased mitmed teaduslikke huve silmas pidavad tööd teistelt erialadelt. Näiteks Eesti Kirjanduse Seltsi kodu-uurimise toimkonna tegevus seoses maakondlike koguteoste väljaandmisega ja koostöös Akadeemilise Ajaloo Seltsi korraldatud ajaloolise traditsiooni kogumisega 1920.-1930. aastatel, Muinsuskaitse Seltsi tegevus 1980. aastate lõpul jm. Majandusgeograaf Edgar Kant kasutas ulatuslikult oma teadustöös nn kohapealseid uurimistöid ehk stipendiaatide vaatlusi ja selle põhjal tehtud kirjeldusi, mis sisult on samuti välitöödel ainese kogumine (Läänemaa 1938, Eessõna; Kant 2007, 7-11). Võib küsida, miks on kasutusele võetud välitöö mõiste ja mille poolest välitöö erineb teistest analoogiliselt tehtavatest töödest. Teisalt on esitatud väiteid, et ka näiteks ajaloo-andmete kogumine arhiivist on teatud vaatepunktist välitöö ${ }^{1}$, sest ajalooarhiivi dokumendid (erinevalt rahvaluulearhiivist) ei ole koostatud teaduslikest ülesannetest lähtudes, mistõttu ajalooarhiivi võib teatud mõttes vaadelda analoogilise folkloristliku välitöö keskkonnana.

Jättes siinkohal lahtiseks välitöö mõiste, käsitleme artiklis esitatud Maidla-uuringuid välitööna, ent artikli lõpus arutleme selle lähenemisviisi (sh mõistevaliku) üle. Seega: siinses artiklis on lähtepunktiks välitööd kunagisel Läänemaal Maidlas (nõukogude ajal Rapla rajoon, praegu Rapla maakond): võrreldakse kohalike elanike küsitlemisel tehtud arheoloogilistel kaevamistel osalenute märkmeid 1987.-1988. aastast (MK: Maidla) ning folkloristliku välitöö materjale 1990. aasta suvest (EKRK I 90, 169-232). Küsimusteks on: (1) kuidas avaldub 1980. aastate teisel poolel üha enam esile kerkinud huvi lähimineviku vastu, kus materjali kogumise meetodiks oli inimeste küsitlemine: külade ja perede ajalugu 20. sajandi esimesel poolel, sh nõukogude ajal varjus olnud Eesti Vabariigi perioodi (kõnekeeles Eesti aja), sõja, metsavendluse ja küüditamise teemad; (2) kuhu asetub 1990. aasta välitöökogemus folkloristlike vaadete kujunemises; (3) mil määral saab kõnesoleva võrdluse puhul rääkida välitööde interdistsiplinaarsusest. Kõik

${ }^{1}$ Kajalood (eetris 21.11.2015), Aro Velmet, https://arhiiv.err.ee/vaata/ kajalood-aro-velmet (31.10.2018). 
need küsimused seostuvad omakorda üldisema teemaga välitöö ja uurimise omavahelisest põimumisest. Lõpuks võib vaidlustada sedagi, mida pidada välitööks.

Artikli esimeses osas tutvustatakse mõlema autori välitöökogemust Maidlas 1980. aastate lõpul ja 1990. aastal. Artikli põhiosas kirjeldatakse Maidla lähiajalugu sealsete inimeste lugude kaudu. Omaette alalõigus käsitletakse kohanimede teemat, tuginedes nii suulistele kui ka ajaloodokumentides leiduvatele andmetele. Artikli lõpuosas tõlgendatakse Maidla-välitöö kogemust kui üht näidet üldisemas uurimispildis. Artikkel on pühendatud Ilmar Jõesoole (1934-2015), kes osutus suurepäraseks Maidla tundjaks ja vahendajaks ning kelleta seda artiklit poleks sündinud.

\section{Kaks välitöö-kogemust}

Kalev. Maidla muinaskalmete ala kaevamised toimusid 1983. aastast 1990. aastani ja järelkaevamised 2011. aastast 2014. aastani Mati Mandeli juhtimisel (Mandel 2017: 7). Osalesin neil kaevamistel alates 1987. aastast Tartu ülikooli ajalooüliõpilasena, muinsuskaitsja, õpetaja ja hiljem arhivaari ameti kõrvalt. Kaevajate seas oli Tartu ülikooli tudengeid ja kodulinnaliikumistega seotud kooliõpilasi Tallinnast ja Haapsalust ning vanu Läänemaa kaevamiste veterane. On tavaline, et kaevajad suhtlevad kohalike elanikega. Praktiliste küsimuste kõrval (kus ööbitakse, kelle maadel tegutsetakse, kus võiks tööriistu hoida jms) on suhtlemise eesmärk saada teavet muististe võimalike leiupaikade kohta. Maidlas oli näiteks põhjust küsida, kas keegi on leidnud põlenud luid või potikilde. Kalmele lisaks oli põhjust otsida muinaskülade kultuurkihte. Kalme lähedalt neid kultuurkihte ei ole leitud, küll aga kaugemalt, näiteks mõisa mäelt, Salutaguse külast Jaani talu juurest ning Maidla külast Naela talu juurest. ${ }^{2}$ 1987. aastal inspireeris uusi küsimusi esitama Eesti Muinsuskaitse Seltsi koostamisel olnud küsimustik (APK 1988). Sellest lähtudes hakkasime sihipäraselt kohalikega vestlema piirkonna lähiajaloo teemadel. Ei olnud haruldane ka see, et külaelanikud, teades kaevajate kohalolekut, otsisid ise kontakti.

Maidla küla vanemast ajaloost rääkis kõige enam ikkagi Ilmar Jõesoo, kes tänu oma vanaisa juttudele teadis kalmest ja päästis sel-

${ }^{2}$ Riikliku kaitse all olevad arheoloogiamälestised, http://register.muinas. ee/public.php?menuID=monument (17.02.2018). 
le ala põlluks kündmisest. Ilmar oli hariduselt ajaloolane, tegutses kooliõpetaja ja kasvatajana Haapsalu sanatoorses koolis. Maidlas pidas ta mesilasi. Ühtlasi oli ta bibliofiil. Olen temaga seotud läbi mitme põlve. Ilmar õppis omal ajal Maidla koolis ajalugu minu vanaisa August Tarendi (1890-1971) käe all, minu isa Aare Jaago õppis Ilmari käe all Olustveres ja mina olin omakorda Ilmari tütre ajalooõpetaja 1986/87. õppeaastal. August Tarendi on kirjutanud mälestusi kodukülast. Olin need lood kaevamiste ajaks juba läbi lugenud. Mul oli isiklikke mälestusi lapsepõlves vanaema ja vanaisa juures Maidlas veedetud ajast.

Kaevamiste ajal külastasime mitmeid lähipiirkonna külasid. Maidlas kirjutasime 1987. aastal üles vestluse nelja külaelanikuga, 1988. aastal lisandus veel kaks üleskirjutust. Need usutlused ja vestlused ei olnud otseselt seotud arheoloogiliste väljakaevamistega. Pigem tulenesid need vajadusest kasutada kaevamistest vaba aega piirkonna ja selle ajaloo tundmaõppimiseks. Vestluste üleskirjutusi ei olnud kavas esitada arhiivile, märkmeid tegid rühma liikmed kordamööda - materjal on kirja pandud erinevate käekirjadega, üleskirjutajaid ja küsitlejaid ei ole kirja pandud. Küsitluste fookus oli informatsioonil (kes, kus, millal). Osalt on esile toodud jutustaja sõnastus või kõnepruuk, samas jutustamisviise või lugusid talletada ei püütud. Need märkmed on taas aktualiseerunud Facebooki rühmas Läänemaa arheoloogiline ekspeditsioon, kus enamasti fotode kommentaarides tulevad taas jutuks ka meenutused kohalike elust. Artiklis kasutatud materjalikogu (MK: Maidla) sisaldab nii neid omaaegseid märkmeid, Maidla-teemalisi sissekandeid minu päevikutes ja kalendermärkmikes kui ka väljakirjutusi arhiivimaterjalidest - viimased hõlmavad peamiselt isikuandmeid. Lisaks on siin ka koopia August Tarendi venna Rudolf Tiigenbergi ehk Ruudi (1895-1973) eluloo- ja küla argielu teemalistest luuletustest. Artikli kirjutamise ajal 2016. aastal külastasime Maidlat kahel korral (juulis kolmekesi, Tiiu Jaago, Enriko Erkmann ja mina ning augustis Tiiu ja mina) ja küsitlesime kuut kohalikku vanema põlve esindajat.

Tiiu. Pärimuse kogu(mist) 1990. aastal raamib eesti filoloogia I kursuse praktika, mida tol ajal algaja õppejõuna juhendasin. Kuna tegemist oli õppetööga, saab kogumispäevikutele ja teksti üleskirjutustele lisaks esitatud praktikaaruandest lugeda tolleaegset kokkuvõtet välitöö eesmärkide ja nende täitumise kohta (EKRK I 90, 23-31). See on tagasivaatavalt huvitav teave mõistmaks mu 
selleaegseid folkloristlikke arusaamu ja otsinguid. Üldjoontes eristub kolm ala: esmalt rahvaluuleteemad, -motiivid, -tekstid, teiseks pärimusrühmad ja nende piiritlemine, kolmandaks pärimuse seotus selle esitusviisidega. Tavapäraseks eesmärgiks oli seni kogutud materjali võrdlusel jälgida, mis varasemast pärimusest on tuntud käesoleva välitöö toimumise ajal (nt usundi ja kommetega seotud olendid-tegelased, silmahakkavalt palju oli Koluvere krahvi lugusid, lastemängude kirjeldusi). Kuid nüüd oli huvi teha seda lähtudes pärimusrühmast: mis tingimustel jutustajad neid lugusid esitasid, miks nad neist asjadest teavad, kuidas nad neisse asjadesse suhtuvad, mis on nende endi meelest oluline, miks jms. Nähtav on ka huvi rahvaluule uute vormide (nt anekdoodid, lähiminevikust jutustamine) ja erinevate earühmade vastu. Esile tuleb arutelu rahvaluule kasutusviiside üle (pärimusrühma-sisesed esitused, folkloorifestivalid vm lavaesitused). Kuigi veel oli lugemata Lauri Honko "Folklooriprotsess" (mis ilmus soome keeles samal, 1990. aastal), ja arutelud rahvaluule uuesti defineerimise üle olid alles algusjärgus, on näha suundumist kontekstikeskse folkloristika põhimõtete omaksvõtmisele. See ei ole siiski ootamatu, sest samal ajal sattusin lugema Dan Ben-Amose rahvaluule defineerimise alast artiklit, täpsemalt selle saksakeelset versiooni (Ben-Amos 1981). Tema käsitlus korrastas minu jaoks eesti folkloristide tööpraktikale tuginevaid arutelusid teemal, kas rahvaluule on pelgalt (minevikust pärit) tekst või ka esitus (nt rahvaluule kui kommunikatsioon, sotsiaalne sündmus vms). Need arutelud olid 1970. aastate lõpul, 1980. aastatel ka üliõpilase ja algaja folkloristi jaoks märkimisväärselt teravad (vt uusi suundumusi nt Laagus 1973 [2009]; Hiiemäe 1978, 38-51; Sarv 2000, 78-94). Ilmselgelt oli huvitav kujundada oma seisukohti olukorras, mis tõi esile põhimõttelised vaadete vastasseisud ja viis sammhaaval ka teoreetiliste raamide nihkumisele kontekstikeskse folkloristika kasuks.

Välitööpraktikast võttis osa kaheksa üliõpilast. Esimesel päeval töötasime kõik koos, seejärel jagunesid üliõpilased kolme rühma. Nii käisime neljas grupis (mina olin omaette), aegajalt kohtudes ja kogemuste üle arutledes. Mina sattusin Maidlasse ühel õhtupoolikul pärast mu kohtumist kohalikku päritolu Haapsalu sanatoorse internaatkooli kasvataja Ilmar Jõesooga. Tema juurde juhatas mind Ilmari kolleeg, samuti põline läänlane Alo Topp, keda tundsin tänu oma Haapsalus õpetajana töötavale õele. Ilmar Jõesoo osutus inimeseks, kes sidus mind edaspidi jätkuvalt nii Maidla kui paljude 
teistegi Läänemaa kohtade ja inimestega. Tänu temale sain näiteks kohalikku ajalugu puutuva teabe Üdruma 1918. aasta sündmusi käsitleva pärimusliku ajaloo teemalise artikli jaoks (Jaago 2009a). Maidlast pärines ka materjal, mille juurde oli põhjust taas ja taas tagasi pöörduda (vt nt Jaago 2009b, 128-129, 134-136). ${ }^{3}$ Külastasime Ilmariga viit kohalikku peret. Esimeses peres, Salutaguse küla Jaanil küsitlesin perenaist peamiselt mina, vestlust osalt salvestades, osalt märkmeid kirja pannes. Teistes peredes tegelesin peamiselt nii salvestamistehnika kui märkmete kirjutamisega, kuid vestlust juhtis Ilmar, sest ta tabas kiiresti ära selle, millest mina olin huvitatud ja eeldas üsna täpselt, mida mina oleksin küsinud. Samas suutis tema, kohalikke inimesi hästi tundes, kiiresti jutuotsale saada. Helisalvestusi üldiselt sel ajal alles ei hoitud, sest sama kassettmagnetofoni linti kasutati korduvalt - linte polnud lihtsalt saada. Suuremat rõhku pandi paberil esitatud välitöö-aruandele. Sellegipoolest jäid mõned fragmendid üle salvestamata, ja nüüdseks on need Tartu Ülikooli multimeedia osakonnas digiteeritud.

Välitöömaterjali arhiiviesitus (EKRK I 90, 169-232) osutab järjekindlalt kahe folkloristliku plaani kohalolekut. Tekst on liigendatud lehe serval esitatud numbritega, mis viitavad rahvaluule liikidele (usundi- või kombealane teave, vanasõnad, laulud jms). Samas on aga rõhutatult esil ajamõõde: millal üks või teine pärimus käibel oli. Enamasti eristub see kahel viisil: kas kõneldavaid asju lihtsalt teati, nendest oldi kuuldud või oli jutustajal nendega (nt õlgnuku tegemine, mardi- ja kadrisandiks käimine) vahetu kogemus. Teine ajajärgu eristumisviis seostub põlvkondadega - neid asju teadsidtegid-rääkisid vanemad, neid vanavanemad jne.

Süvenemisel tekstidesse ja eriti sellesse teabesse, kuidas või miks üht või teist asja teati kõneldavat, joonistus välja nii põlvkondade kogemus ja repertuaar kui ka selle vahendamine põlvkondade vahel. Minu kui folkloristi arengu seisukohast oli see väga tähtis, kuna see haakus minu teoreetilise huviga, kuidas on omavahel seotud pärimus ja selle olemasolemise tingimused. Need otsingud leidsid

${ }^{3}$ Viidatud artiklis on kasutatud sama välitöö käigus Ristil salvestatud Maidlaga seotud kääpa teerajale astumisest põhjustatud eksimislugu. Jutustajaks oli Eliise Tamm (1904-2002), salvestajateks-küsitlejateks üliõpilased Mari Koik, Jakko Väli ja Terje Kruusimaa (EKRK I 90, 113-114). Lisaks sellele on Tiiu Jaago ja Kalev Jaago küsitlenud Eliise Tamme tütart Ainu Tikenbergi Ristil 27. juulil 2009. aastal (MK: Läänemaa 2009, CD: Ainu Tikenberg). 
väljundi pärimusliku ajaloo suuna leidmises ja ka rahvaluule defineerimisel 1990. aastate teisel poolel, 2000. aastate alguses. ${ }^{4}$

\section{Maidla kui välitöö-ala}

Maidla asukoha on kohalik laulik Rudolf Tiigenberg määratlenud kui seitsme linna vahe-risti. Need seitse linna on Tallinn ja Paldiski, Risti ja Märjamaa, Lihula ja Haapsalu, ning Pärnu (MK: Maidla, Tiigenberg 1956). Tiigenbergi laulu-geograafia lähtus selleaegsest bussiliiklusest. Tänapäeval nii ohtralt busse sinna ei vii, Koluvere ja Märjamaa vaheline tee on ehk kõige kindlam orientiir leidmaks kõnesolevat piirkonda.

Praegune Maidla küla koosneb mitmest endisaegsest külast ja artiklis on kogu piirkonda nii nimetatud. Ent tekstides kohtab varasemaid külanimesid nagu Salutaguse (mis tsaariajal oli Kullamaa kiriku, mitte Maidla mõisa alla kuulunud küla, enne Teist maailmasõda kuulus see Maidla I küla alla); tsaariaegne Ullimulla (mida hiljem, 1920.-1930. aastatel nimetati Nõmme külaks ja mis kohanimeraamatu väitel liideti hiljem Laukna külaga (EKNR 2016, 306), kuid talude järgi kontrollides on näha, et suurem osa Nõmme külast liideti Maidlaga); Käoküla ehk Kaeküla (mis jagunes Suureks ja Väikseks Kaekülaks). 1977. aastal ühendati Maidla ja Salutaguse külad Tika talult laenatud uue, unikaalsemaks peetud nime alla (EKNR 2016, 359). Kohalikud inimesed kasutasid erinevatel aegadel olnud koha- ja külanimesid, sõltumata jutustamisaegsetest ametlikest nimetustest. Lisaks võib kõrv kohalike jutuvoost kinni püüda sellised kohamääratlused nagu alt küla, taga Maidla, ees Maidla, Nõmme taga, kuid neil puhkudel ei ole tegemist väljakujunenud kohanimedega, need on pigem orientiirid, kuidas jutustaja kirjeldatavat asukohta enda asukoha suhtes paigutab.

Maidla kaevamised toimusid endise mõisa karjamaal, kuhu Eesti Vabariigi esimestel aastatel olid eraldatud maatükid

${ }^{4}$ Rahvaluule defineerimisel osutus oluliseks rõhutada pärimuse mitmetasandilisust (esteetiline, teadmisi ja kogemusi hõlmav) ning pärimuse püsimise seost selle kasutamise ja ühtlasi paindliku muutumisega (Jaago 1999). Pärimusliku ajaloo mõiste avamisel olen rõhutanud, et tegemist ei ole mitte üksikute ajalugu puudutavate lugude või teemade uurimisega. Oluline on jutustajate, pärimuse valdajate enesemääratlusega seotud minevikutõlgendus tervikuna, täpsemalt, see ajalookäsitus kuulub jutustajate/ pärimusrühma identiteeti (Jaago 2005, 10). 


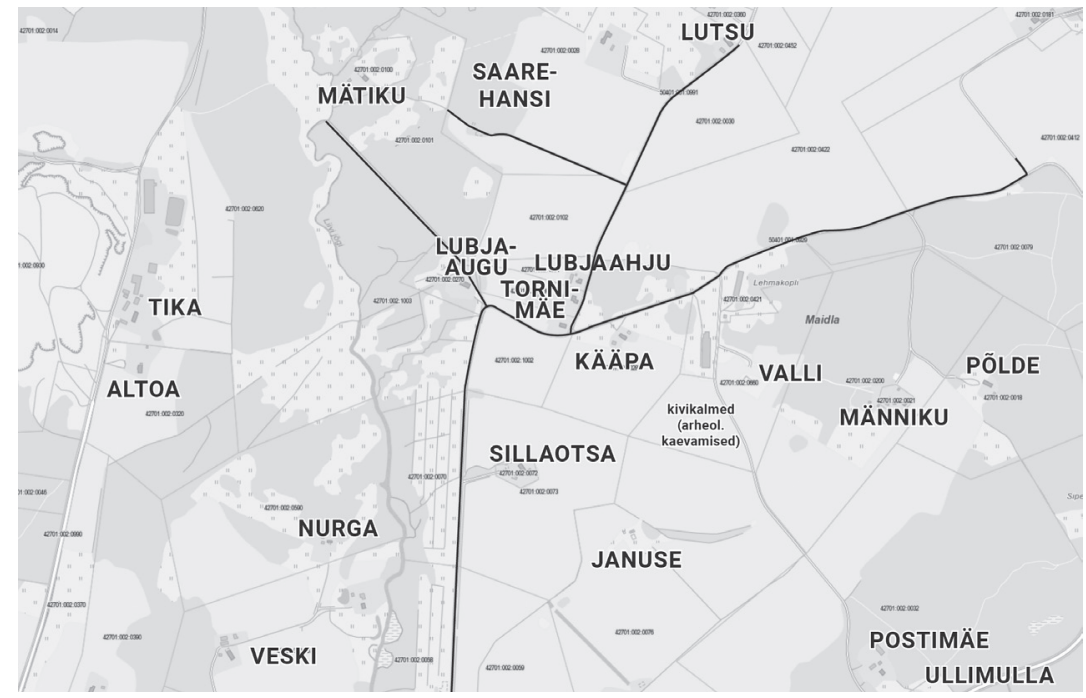

Skeem 1. Maidla kivikalme (Maa-amet, http: / /xgis.maaamet.ee/maps / XGis?app_ $i d=U U 82 A \&$ user_id $=a t \& L A N G=1 \& W I D T H=1274 \& H E I G H T=938 \& B B O X=507520$ $.30253908,6532604.8226957,510008.58378908,6534436.8539457 \&$ setlegend $=S H Y$ BR_ALUS01_82A=0,SHYBR_ALUS07_82A=1).

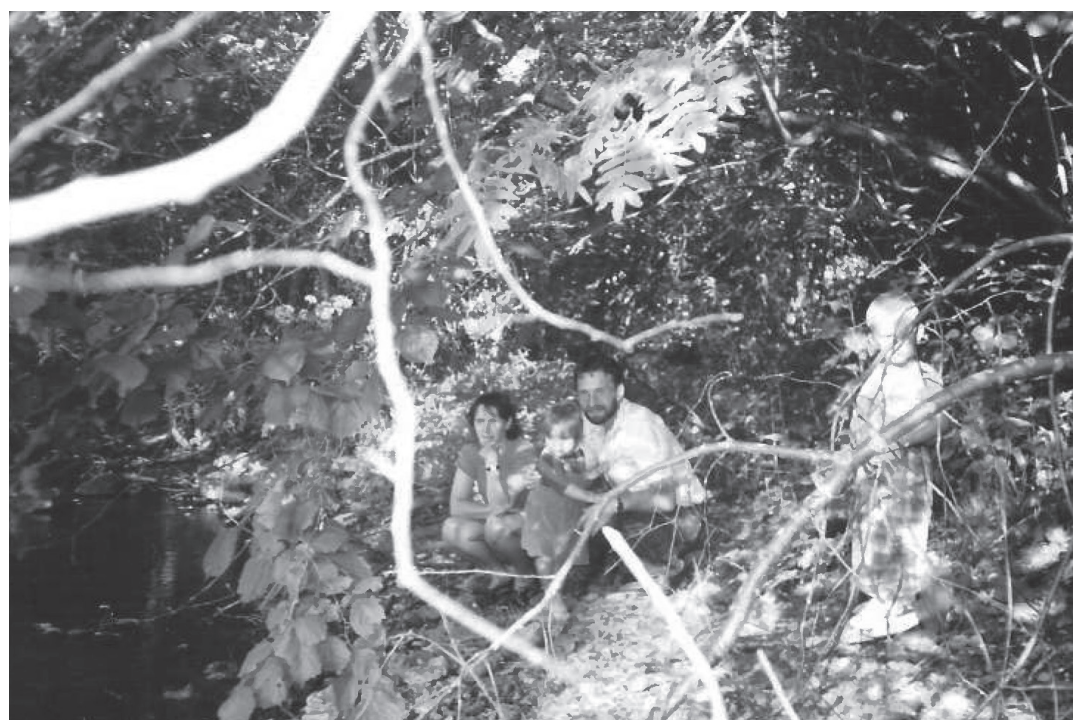

Artikli autorid koos Ene ja Meelisega Koonusmaa ohvriallikal 1995.

Foto: Ilmar Jõesoo. 


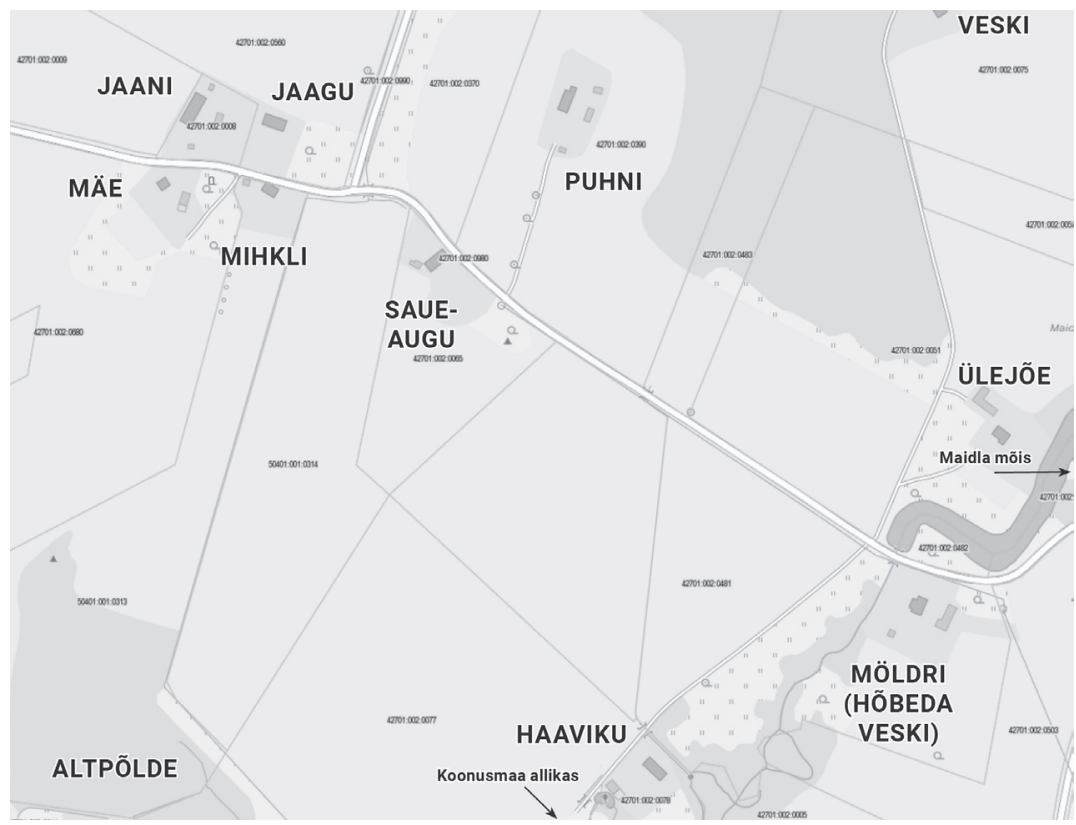

Skeem 2. Salutaguse ja Maidla mõisa naabrus (Maa-amet, http: / /xgis.maaamet. ee / maps /XGis?app_id=UU82A\&user_id=at\&LANG=1\&WIDTH=1383\&HEIGHT $=938 \& B B O X=505969.03300786,6532143.8851958,507319.61894536,6533059.9008$ 208\&setlegend=UUKAT1_82=1,SHYBR_ALUS01_82A=0,SHYBR_ALUS07_82A=1).

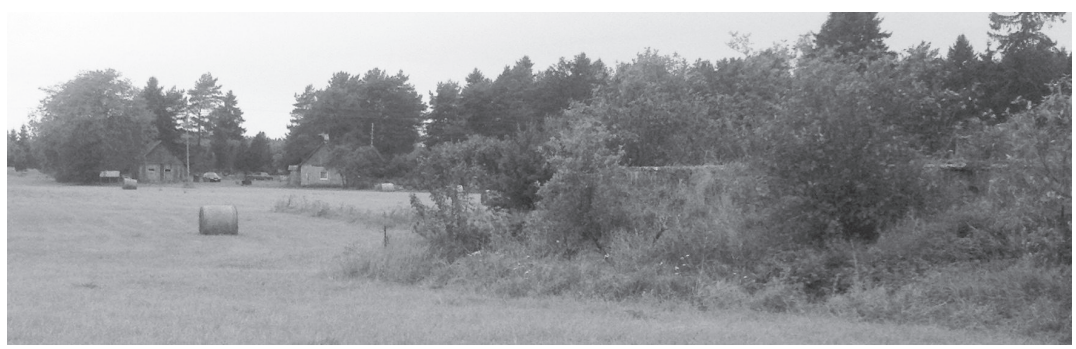

Kääpa. Foto: Tiiu Jaago, 2016. 


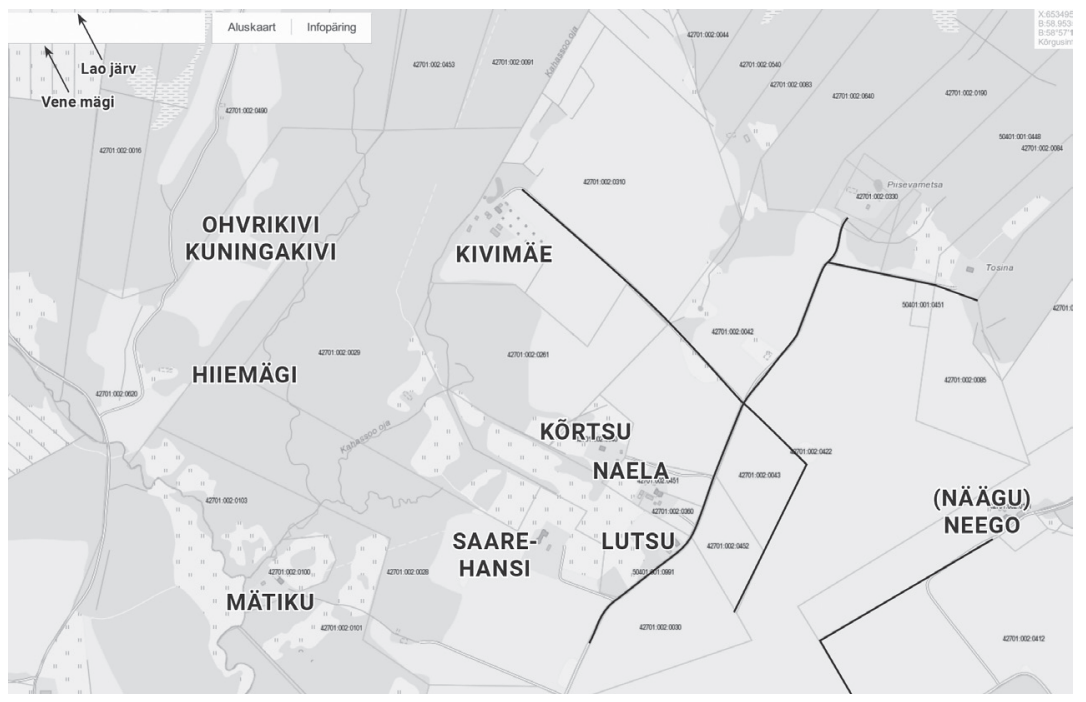

Skeem 3. Maidla raba-poolne osa (Maa-amet, http://xgis.maaamet.ee/maps / XGis?app_id=UU82A\&user_id=at\&LANG $=1 \& W I D T H=1383 \& H E I G H T=938 \& B B O$ $X=506486.61113286,6534146.8148833,509187.78300786,6535978.8461333 \&$ setlegen $\left.d=U U K A T 1 \_82=1, S H Y B R \_A L U S 01 \_82 A=0, S H Y B R \_A L U S 07 \_82 A=1\right)$.

asundustaludele: seal on Kääpa, Valli, Männiku, Sillaotsa, Jaanuse ja Postimäe (vt skeem 1).

Kalme lähedalt ei ole leitud muinaskülade jälgi. Küll aga on varasemaid kultuurkihte leitud Maidla külast Lutsu, Anni, Naela ja Kõrtsu talu piirkonnast, samuti Salutaguse külast ja mõisa mäelt (vt skeem 2 ja 3 ).

Kaevajad elasid Maidla jõeks kutsutud, ent ametlikult Liivi jõe ääres Mätikul perenaise surma järel sovhoosi käsutusse jäänud majas (vt skeem 1 ja 3). Allpool jõe ääres on veel Hõbeda veski (ametlikult Möldri) ja Koonusmaa talu, mille lähedal on ohvriallikas (vt skeem 2).

Vasakul pool üle jõe raba ääres olid omaaegsed hajatalud Tika, Alttoa ning nüüdseks kadunud Aama, Salusilla, Hiie, ja neid oli veel (vt skeem 1). Raba serval on Hiiemägi, sealt kaugemal rabas on Vene mägi ja Lao järv (vt skeem 3). Viimasega on seotud küla minevikku puudutav lugu.

Kaevajad külastasid 1987. aastal nelja külaelanikku: Harald Rudolf Tederovi (1914-1993) Loigult, Eva Popsi (1922-2000) ja 
tema ema Miina Laurikut (1893-1989) Põldeotsalt, Kolu Hildat ehk Hilda Kollot (1906-1990) Saueaugult. 1988. aastal küsitleti Linda Laanemäed (1909-2002), kelle lapse- ja noorpõlv möödus Lepikul, küsitlemise ajal elas ta aga külanõukogu, endise vallamaja ruumides. Lisaks viis Ilmar Jõesoo Kalev Jaago Anni tallu küsitlema Karl Vaske ja tema poega Albertit. (MK: Maidla 1987, 1988.)

Rahvaluuleretkel olid kõnelejateks 56-aastane Ilmar Jõesoo (EKRK I 90, 169-195; vt ka eluloo-intervjuu MK: Läänemaa, Jõesoo 2012; MK: Maidla 2014), 78-aastane Hilda Laanert, (s 1912) Jaanilt (EKRK I 90, 195-206) ja 74-aastane Liisi Tammet (s 1916) Haavikult (EKRK I 90, 207-216), kes olid Salutaguselt (vt skeem 2), 61-aastane Aliide Müürsepp (s 1929) Maidla Kääpalt (EKRK I 90, 217-221) ning kaevajate küsitletutega kattuvad 81-aastane Linda Laanemäe (EKRK I 90, 221-230) ning 84-aastane Hilda Kollo (EKRK I 90, 230-232).

\section{Päritolu- ja kohapärimus}

Ilmar Jõesoo kõneleb oma eluloointervjuus, et tema emapoolne suguvõsa on elanud Maidlas 12 põlve (MK: Läänemaa, Jõesoo 2012). Suguvõsa põlistalu on Lutsu. Lutsu esmamainimine on 1569. aasta vakuraamatus Kaekülas, mis tol ajal jäi Kaeküla (Kayenkyla) vakusesse (SRA, Balt. Fögd. 387, 1568-1570). Ilmari emaliini esiisa Lutsu Siimu mainitakse aga Maidla mõisniku testamendis 1637. aastal (EAA.858.2.2154). Viimane Lutsu rendiperemees Ilmari suguvõsast oli Aadu. Aadul lapsi ei olnud, mistõttu mõisnik andis talu teisele. Aadu vend Hans (Ilmari vanaisa vanaisa) läks koduväiks naabertallu Hansile, mis sai Ilmari esivanemate taluks. Hansu poeg, Ilmari vaarisa $\mathrm{Karl}^{5}$ ostis 1901. aastal Hansi talu päriseks

${ }^{5}$ Karl Baumann, 1842-1929 (EAA.1243.1.211, 1.257p). Karl Baumanni (üleskirjutuste juures on nimekuju Kaarel Bauman) on küsitlenud Eesti Kirjanduse Seltsi stipendiaat Leida Mauer 1924. aastal ajaloolise traditsiooni kogumisaktsiooni käigus. Selle välitöö aruandes on mh mainitud, et ta on 84-aastane, on käinud Maidla mõisas teol. Temalt on teavet mitmes temaatilises alajaotuses: 1. Traditsiooni ajaloolistest paikadest (Karl Baumann jutustab Vene mäest, kus Vene-Rootsi sõja ajal olnud venelased laagris. Kui ta oli veel poisike, mäletab, et üle mäe läks midagi kivitee taolist); 2. Ikaldusaastad ja näljaajad (kui ta 15-aastane oli, oli suur nälg olnud); 3. Koolera (ta oli umbes 10-aastane, kui oli koolera-epideemia ja talud jäänud üsna tühjaks); 4. Traditsiooni mõisnikest ("Kui Maidla krahv (L. v. Buxhövdeni lell) maanteel vastu juhtunud, pidanud talumees 
(EAA.2840.1.18278). See 60-tiinune talu oli küla üks suuremaid. Ilmar sündis Hansi tagakambris 1934. aasta 6. aprillil. Paar aastat hiljem ostis Ilmari isa naabruses Lutsu maadele rajatud Saare talu. Talu sai nime suurest saarepuust, mis kasvas praeguse aida taga. Ilmar mainib, et tema võttis puu maha, kuna see oli teiste puude suretaja ${ }^{6}$. Saare elumaja ehitamise ajal elatigi selle saarepuu alla ehitatud püstkojas (MK: Maidla 2000). Ilmari lapsepõlv möödus vanemate kodus Saarel ja vanavanemate kodus Hansil. Kuid tema noorpõlve kuulus ka Lutsu: kuna selle viimase peremehe (Jüri Matsi, 1875-1958, elk.88.0.19) surma järel jäi elumaja lagunema, küttis Ilmari isa selle maja ära. Lutsu talumaja oli olnud õlgedest täiskelp-katusega, peauks Saare poole, nagu mäletab Ilmar. Lutsu talu nimega seoses rääkis Ilmar loo ajast, kui Maidla jões veel lutsu sai püüda ja kuidas ka tema õppis neid libedaid kalu käsitsi püüdma. Kala maitses Ilmarile hästi.

Vanaisa $^{7}$ näikse Ilmari elus olevat mänginud olulist rolli. Näiteks mesilastega hakkas ta tegelema nimelt tänu vanaisale. (MK: Läänemaa, Jõesoo 2012; MK: Maidla 2014.) Ent antud juhul on veelgi olulisem, et enamik kohalugusid on ta kuulnud vanaisalt. Näiteks Koluvere krahvi ja taluinimeste omavahelisi suhteid kajastav lugu:

Aga ta [Koluvere krahv Buxhövden] oli rahva suhtes tähelepanelik.

Sest vanaisa rääkis, et tema isa jutustas ${ }^{8}$, kuidas mõisa põllul

(kas koormaga, tühjalt ehk jala - ükskõik) teelt kõrvale jooksma, muidu ajanud härra isiklikult piitsaga sinna (see olnud teoajal). Kui talumehed Kolovere proualt puid küsima läinud - käskinud ta sõnnikuga ahju kütta"); 5. Pärisorjus (Karl Baumann on vanadelt inimestelt kuulnud, et inimesi on kasside ja koerte vastu vahetatud); 6. Teoorjus (Karistustest: "B. Isa saanud 40 hoopi mõisatallis ütlema minnes, et katkise vankri tõttu on vooriminek võimatu. Naabriperemees saanud peksa selle eest, et end kohast lahti öelnud. Kui B. 13-a. poisikene olnud, lasknud kord Maidla krahv Maidla vesiveski lähedal suure kivi pääl kõik teolised läbi peksa, kes päikesetõusu ajal veel tööl pole olnud. Krahv vaadanud peksmist pealt. B. arvab, et kubjas teoliste pääle hiljaksjäämise pärast kaebama läinud, mille tõttu siis krahv sarnase ootamatu karistuse korraldanud"; "Teolistele pandud leivakotti harilikult piima (pooleks kaljaga), soola ja leiba, väga harva - suvel - ka silku. Leib olnud väga aganane, ainult jõulupühade ajal söödud puhast leiba. Inimesed aga olnud rõõmsad ja prisked") (EKLA f 200, $3: 2, \mathrm{lk} \mathrm{2,} \mathrm{29,} \mathrm{35,} \mathrm{46,} \mathrm{56,} \mathrm{68,} \mathrm{80).}$

${ }^{6}$ Kaldkirjas on siin ja edaspidi esitatud jutustaja sõnastus.

${ }^{7}$ Eduard Baumann, 1886-1968 (elk.88.0.10).

${ }^{8}$ Rõhutused tsitaatides siin ja edaspidi artikli autoritelt. 
külvatud rukist, ikka talumeestel ka, et mõisa köis, las lohiseb, ja võeti ikka oma jaoks. Jäeti siis üks kotikene kivi taha peitu, et see siis õhtul ära viia. Ja talumees läks krahvi juurde: "Näe, seemnest tuli veidi puudu, ei saand põldu täis külvata." Krahv oli ütelnud, et mine võta siis kivi tagant ja külva põld täis. Ta oli lossi tornist pikksilmaga vaadanud, mis ümbruses toimub. Nii on see lugu meelde jäänud. Seda rääkis vanaisa, tema isa oli niiviisi rääkinud. (EKRK I 90, 173-174; vrd EKRK I 90, 107)

Viitega vanaisale (või ka vanematele inimestele) tuleb juttu veel Lao järvest, Käokülast (Kaeküla), Vene mäest (mille kohta oli ajaloolise traditsiooni kogujale 1924. aastal kõnelenud ka Ilmari vaarisa Karl, lisades, et sealt läks üle mäe midagi kivitee taolist; samas kogus on 76-aastane Jaan Silberberg aga Vene mäe seostanud Poola sõjaga, nii et kuuliaugud Koluvere lossi mü̈̈ri sees olevat sel ajal Vene mäelt lastud; EKLA f 200, 3:2, lk 2); Hiie talu juures olevast hiiekohast ja Rootsi kuninga kividest (EKRK I 90, 176-178). Maidla külla üles pandud kohaliku "Kultuuri- ja looduslike vaatamisväärsuste" plaanilt võib neist kohtadest leida Peeter I vägede peatuspaiga (ehk Vene mäe) ja Rootsi kuninga kivid (MK: Maidla 2016). Kõik need Ilmari mainitud kohad on lugudes seotud sõjaajaga: Käoküla (Kaeküla) on nüüdseks kadunud, ent Põhjasõja (või ka Poola sõja) ajal oli seal lähedal Vene mäel Vene sõjavägi olnud. Ilmar räägib loo, mille järgi külainimesed olid vene sõjameeste eest rabas paos Lao järve ääres. Et pääseda sõdurite käest, olid nad endale kivid kaela sidunud, kätest kinni võtnud ja tagurpidi endid Lao järve uputanud.

Aga nähtavasti kõik inimesed ei uputanud, sest minu esivanemad ulatuvad tagasi enne Põhjasõda. Ja vanemad inimesed teavad seda legendi ikka veel rääkida. Minule rääkis selle loo ära vanaisa. Vanemad inimesed teavad seda kõik. (EKRK I 90, 176)

1990. aastal teadis seda lugu viiest külaelanikust üks, kõige noorem, 61-aastane Aliide Müürsepp Kääpalt:

Kuulnud olen. Et jälle, kui pärisorjuse ajal see raske elu oli, siis küla noored pannud kamba kokku, olnud üksteise käest kinni ja läinud tagurpidi senna Lao järve, uputanud endid ära, et hirmsast orjaraskusest pääseda. Vaat seda olen ma kuulnud, aga rohkem ma ei tea. (EKRK I 90, 218)

Tema teadmistes on Lao järve lugu seotud mitte sõja- vaid pärisorjuse ajaga. Ühtlasi on tema midagi kuulnud ka Vene mäe kohta: 
"sealt pidi mingi trepp üles minema", küsib ta Ilmarilt kahtlevalt, ent sellele ei järgne vestluses midagi, mis öeldut täpsemalt selgitaks. (Võimalik, et see trepp oli meenutus samast kivitee taolisest teest, mida mainis Karl Baumann 1924. aastal ajaloolise traditsiooni kogujale Leida Mauerile.) Vene mäge teadis teinegi Ilmari eakaaslane Laine Alasi, keda küsitlesime 2016. aastal. Ta kirjeldas seda kui huvitava taimekooslusega väga ilusat kohta madalamas rabaosas ja lisas "Legendi järgi on Peeter I seal peatunud oma ratsaväega" (MK: Maidla 2016). Raba serval asuva Hiie talu kohta teadis Ilmar oma vanaisalt kuuldu põhjal rääkida, et seal on muistne hiis ja Rootsi kuninga kivid, kus olnud omal ajal suur lahinguväli (EKRK I 90, 178). Neist ei tea Aliide ega ka temast vanema põlve inimesed midagi. Tikamäe kohta teab 78-aastane Hilda Laanert, et venelased matnud sinna oma hobuseid. Kuid ta ei anna ajamääratlust ega selgita ka, kus, millal või millega seoses ta seda kuulnud on. Ilmar Jõesoo mäletas, et see olnud 1941. aastal ja et sinna olid maetud ka omade poolt mahalastud punaarmeelased. Sõites mõisast Saare talu poole ei jätnud Ilmar näitamata jõe ääres asunud Pajumõisa karjalauda varemeid ja Lubjaahju talu juures rääkimata seda lugu, kui Maidla mõisa valitseja Jaan Kruusmaa, tema sugulane, sai rikkaks ja mõis jäi vaeseks. Lutsu maadele jõudes rõhutas Ilmar, et siin asus ka küla magasiait. (MK: Maidla 2000.)

\section{Argielu ja seltsielu}

Hilda Laanerti, Jaani perenaise esivanemad on Salutaguse külla tulnud viis põlve tagasi Hiiumaalt. Siis istutas esiisa talu väravasse kaks jalakat (ehk jalangat, nagu Hilda ise ütleb), mis kasvasid seal kõigi viie põlvkonna ajal, neist üks on praegugi alles (MK: Maidla). 1990. aastal ta oma pere ja küla ajaloost palju ei räägi. Mitmele asjale osutab õieti Ilmar. Küll aga esitab ta meelolukaid helimaastikke oma lapsepõlvest. Näiteks, kui vilja peksti, siis pidi ilusasti kõlama paaris "Hunt saunas, hunt saunas". Kui see ei õnnestunud, siis kõlas "Kukepüksid, kukepüksid” (EKRK I 90, 195). Tema mälestuste hulka kuuluvad jõuluaja kirjeldused: kuidas Kullamaa kirikuõpetaja Brasche (Hilda öelduna kõlab see õpetaja Praase) ${ }^{9}$ ja tema proua lihtrahva lastele jõulupuid korraldasid; et sel ajal olid jõulujumalateenistused hommikuti, pärast teda aga õhtuti, ja

9 Arved Brasche (1878-1938) oli Kullamaa pastor aastatel 1902-1931 (Aarma 2014, 66). 
kuidas hobustega Kullamaa kirikusse sõideti. Lõpuks rõhutab Hilda kui ilus oli vaatepilt kiriku juures - hobustel olid kirjud tekid peal, nagu lilleaed seal aja ääres, ja kirikust tagasi koju sõideti võidu, kellad paukusid peal (EKRK I 90, 198).

Usundi ja kommetega seoses kõneleb Jaani perenaine küla argielu muutumisest (meenutatagu, et ta sündis vahetult enne Esimest maailmasõda, 1912. aastal): tema lapsepõlves sõid loomad vabalt seal kus tahtsid, hiljem piirati karjamaad aedadega (vrd Pärdi 1998, 105-107). Sellel varasemal perioodil tehti kunste (nii nimetab tema ja teisedki usundilisi toiminguid), mis pidid tagama karja kojutuleku. Näiteks tuli esimese karjapäeva vits koju tagasi tuua, et kari koju jõuaks. Ilmneb, et loomi ei käidud otsimas - kari pidi ise koju tulema. Ühtlasi teab ta oma lapsepõlvest kurja silma mõju loomadele - mõni kartis seda, et nõiatakse loomad ää. Nõidusi ehk kunste teab palju ka Hildaga samas külas elav Liisi Tammet Haavikult (tema oli sündinud Esimese maailmasõja ajal 1916. aastal). Kuid temagi mäletab seda oma lapsepõlvest, mitte hiljem:

Olid pidand, jah, ennemalt neokesi kunstisi, et kui teene näeb, siis teene nõidab ää, või jääb aigeks või õnnetus, või looma kohta: kui mõni ütleb, et sul ilus lehm, siis võib loom aigeks jä̈̈da. Olid pidand, jah, nihukesi kunstisi. [Naer.] Noh, arvamine. (EKRK I 90, 209)

Küsimusele, kas nüüd ei ole kurja silma, vastab Liisi:

Ei ole, nüüd [kolhoosis] on kõik [loomad] ühised: näha kõik, mis näha. Ja kui keegi loom otsa saab, see viiakse kuskile ja maetakse maha, kui ta surnd oo. Ei seda aeg pole keegi nõiand ühti. (samas)

Hilda Laanert teab küllalt palju ilmaendeid, mis lähtuvad loomade ja lindude käitumise vaatlemisest. Ilmavaatlused ja -ended on valdkond, mille kohta tema ütleb: vanemad inimesed teavad seda kõik (EKRK I 90, 196, 198, 202-203).

Liisi Tammeti ja Hilda Laanerti jutust tuli hästi esile, et mõni uskus kunste ja teine jällegi mitte. Hilda kodus kunste ja nõidumist ei olnud ja nendega ei tegeldud. Tema noorpõlve kuulus pigem Kullamaa seltsielu, millest ta aktiivselt osa võttis: "Ei olnud nii palju päevi kohe, kui tahtsid" (EKRK I 90, 200). Ta nimetab Perenaiste Seltsi ja Kodukaitse korraldatud tuluõhtuid ja igasugu õhtuid. Perenaised tõid nii toiduained, millest koos kuklikuid tehti, poest osteti vorsti, suhkrut ja kohvi. Enamasti oli tee, teeõhtud (EKRK I 90, 201). Koos tehti võileibu sellest, mis peol osalejad kodust kaasa olid 


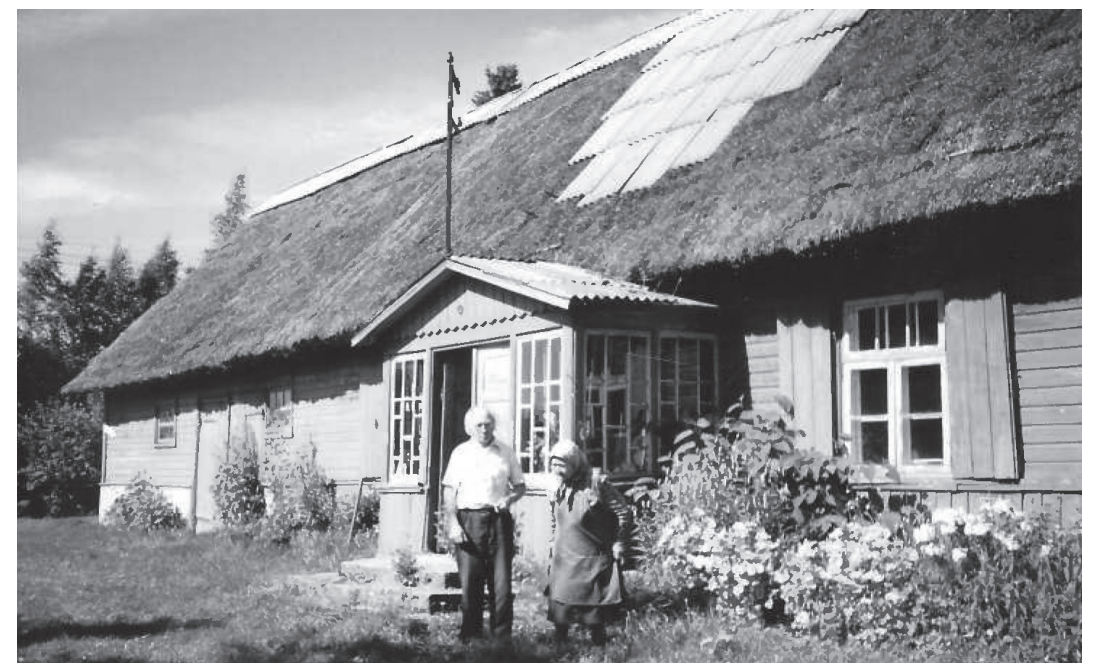

Ilmar Jõesoo ja Liisi Tammet Haaviku õuel 1995. Foto: Tiiu Jaago.

võtnud (vorsti-, kilu, keedutud soolaliha võileivad). Neist õhtutest mäletab ta mänge ("Kes aias", "Tibu-tibu, ära näita"), puhkpilliorkester mängis, tantsiti. Kuid viinavõtmist ei olnud, rõhutab Hilda. Pärt Ellerhein oli sel ajal koorijuht Kullamaal ja Hilda koos õega käis kooris laulmas. Nii käidi ka laulupidudel Haapsalus, Tallinnas ja Lääne-Nigulas ning kirikus sai ühtelugu kontserti antud (EKRK I 90, 200).

Kaevajatele on aktiivsest seltsiliikumisest ja eriti kooridest ja proovidest sõja-eelses Maidlas kõnelenud Hilda Kollo (MK: Maidla 1987). Arheoloogide huvi nende teemade vastu tõukus nõukogude lõpuaastatele omasest aina kasvavast Eesti aja huvist. Lugudest tõusid esile sõjaeelsed kohalikud avaliku elu tegelased, peamiselt haridus- ja muusikategelased. Hilda Kollo nimetab koorijuhti Ruut Kurepalu, kooliõpetajaid Karl ja Villem Leitalu. Ka pajatab Hilda mõisa-aegsest koloniaalkaupluse pidajast Põldeotsal Hans Popsist, kes läks pankrotti. Pankrotist oli järele jäänud niipalju raha, et Pops sai pojale saksofoni osta (MK: Maidla 1987).

Hoopis teistsugusest vaba aja veetmisest räägib Hilda Kollo 1990. aastal folkloristile. Siis kõneleb ta pikalt ja emotsionaalselt 
külapidudest ja tantsimisest lõõtspilli saatel Kesknõmmes (EKRK I 90, 230-231). Kesknõmme pidusid mäletavad ka praegused vanema põlve inimesed: Oli ilus plats. Pingid olid pandud. Nü̈̈d ei tunne Kesknõmmet enam äragi (MK: Maidla 2016). Kuid nemad, sõjajärgsed noored, seal enam ei käinud. 1956. aastal Maidlasse tulnud naine ei tea aga Kesknõmme asukohtagi. Aare Laanemäe meenutab, et Kesknõmme peod taandusid 1951. aastal, seoses Laukna rahvamaja avamisega (Laanemäe 2012, 73). Laulik Ruudi kirjutab 1956. või 1957. aastal Kesknõmmest:

Kesknõmmes see kruusaauk.

Ligidal tantsuplats, kus pauk.

Kolmkümmend kolm (neli, viiski) aast noorsoo jalg.

Ärevil ise olnd, rõõmus palg.

Jaanipäe aeg lõket tehti.

Ritvi ei püstitatud ühti.

Kõrge kuuse metsa tõttu

Poleks seda kuskis ikka nättu.

Ridva jaoks peet teine koht.

Kahes kohas küll ei olla toht.

Seks poleks jätkundki noort sugu.

Lõke on, pole ridvast lugu.

Ritv vanast kõrgus kadaka mäel.

Sealt läks komme Terava mäe pääl.

Oluliselt see üks sama platoo.

Teisel serval vaid teine nimi oo.

Kaks-, kolmsada sammu pikkust tool.

Nü̈̈d aastad läind ja Kesknõmmes

mets (kuusik) ikka nohiseb.

Hall vana põlv neid kohtasi mälestustes külastab.

(MK: Maidla, Tiigenberg 1956/57)

Ühelt poolt tuleb esile, milline see tantsuplats oli - lagendik kuuskede vahel. Teiseks on selge, et Kesknõmme on peoplats mälestustes. Tähelepanu aga äratab jaanitule kirjeldus. See on seda huvitavam, et sõjajärgsed noored, praegused vanema põlve elanikud arvasid, et Kesknõmmes jaanituld ei tehtud, et jaanitule komme tuli hiljem, kolhooside aeg (MK: Maidla 2016). Huvitav on ka kirjeldus, et lõke oli, ent tuld ei tehtud ridva otsa. Ilmselt kõneleb 
see jaanitule kombe ja jaanitule tegemise koha muutumisajast (vrd Hiiemäe 1985, 49-62).

Sõjaeelsest mardi-, kadri, jõulu-, nääri- ja vastlakommetest jutustab Linda Laanemäe. Tema mitte ainult ei tea, et tehti õlgnukku ja seda, kuidas seda nukku õlgedest seoti. Tema nägi, kuulis, tegi kaasa ja teab, et õlgnuku viimine naabri ukse taha ei olnud sugugi kerge, sest koerad hakkasid ju haukuma ja reetsid pererahvale nukutooja. Kõik see tekitanud aga palju põnevust (EKRK I 90, 221-227).

Meelelahutuslikke eestiaegseid kunste ehk aastavahetuse õhtul ette võetud ennustamisi mainib ka Liisi Tammet:

Viskad kingad või kalossid (lähed näoga ukse poole õue) ja viskad siis üle õla, näed, kumba pidi kukub. Kui kannad väljapoole jäävad, siis jääd senna majasse. Kui ninad jäävad, siis läed välla. Ja kui risti-põigiti oo, siis ei tea, mis segadust tuli. (EKRK I 90, 210-211)

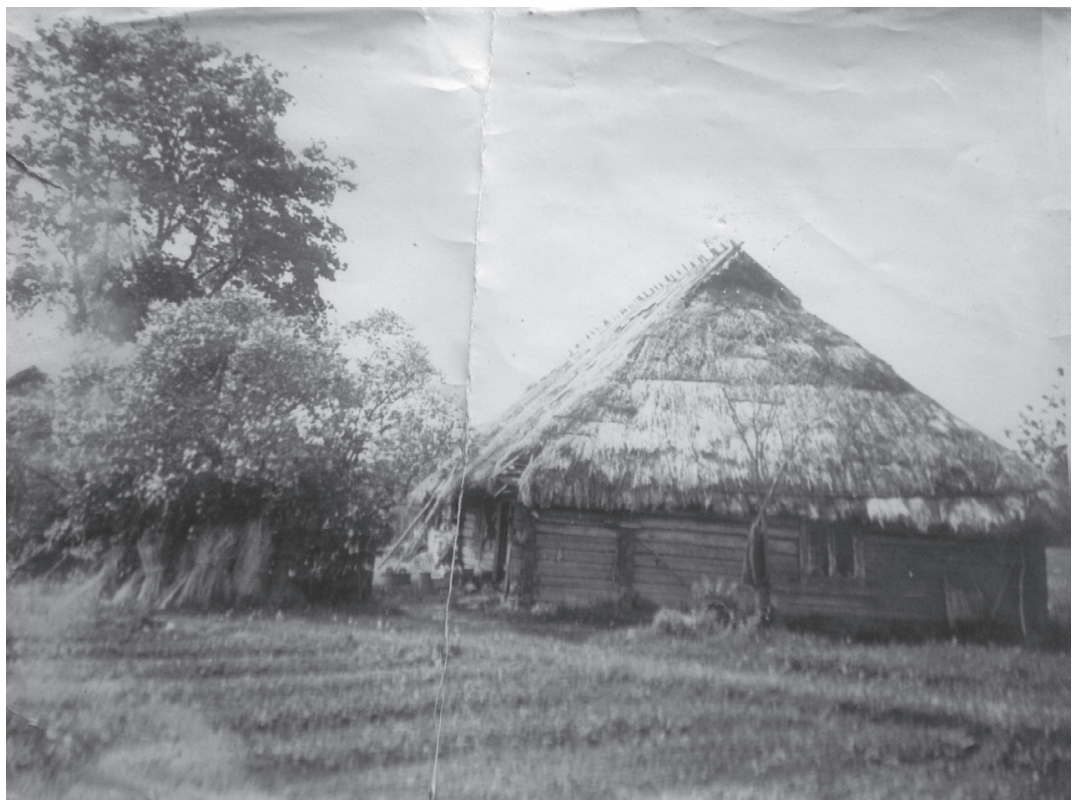

Linda Laanemäe lapsepõlvekodu Lepiku suitsutare. Foto erakogust. 
Tuleb esile kolm vaba aja veetmise ala: koorilaul ja seltsitegevus Kullamaal, ümbruskaudsete külade noorte tantsupeod Kesknõmme lagendikul ja naabriperede vahelised koostegemised kalendritähtpäevadel. Samas ei tohi unustada, et meelelahutus ei võimaldanud töödest kõrvalejäämist - ikka rõhutatakse, et polnud nii palju päevi, kui vaja või et hakati tööle kohe, kui kael kandma hakkas.

Kaevajate märkmetest tuleb Hilda Kollolt kuulduna esile veel üks kohalik meelelahutus, see on usuliikumistest lähtunud jutlustamised, mis sealkandis olid kaunikesti populaarsed (vrd EKLA f 200, 3:2, 100-102). Kõik need kirjeldused seostuvad 1920.-1930. aastatega, ometi ulatuvad traditsioonid ja jutuotsaniidid ka 19. sajandi lõppu, 20. sajandi algusse.

\section{Teated muinasajast ja lähiminevikust}

Kaevajate märkmetest tulevad enim esile mahavaikitud lähimineviku-teemad. Nad elasid kaevamiste ajal Mätikul, kus nad leidsid tapeedi alt Leningradist vanglast 1949. aastal saadetud kirja. See oli Mätiku perepoja Johannes Soomi (enne eestistamist Silberberg, s 1921) kiri omastele (MK: Maidla, Soom). Kiri tekitas toona - Nõukogude aja lõpul - erilist huvi, sest kogu see teema, nagu ka sellega seotud tõendid, olid tabu. See oli kolmnurkselt kokkuvolditud margita venekeelse aadressiga kiri. Kiri oli saadetud Hiie tallu, mitte koju ja sisaldab kirjutaja muret koduste saatuse pärast. Kirjas palub ta saata endale raha, liha, seepi ja tubakat. Ta annab teada, et on terve ja loodab taas kõiki näha.

Nii oli ootuspärane, et küsiti Mätiku omaaegsete elanike ja saatuste kohta. Harald Tederov Loigult väitis, et Mätiku metsavend (Johannes Soom) varjas ennast Tika metsas. Mätikult pärit Eva Popsi ema Miina ütles, et tema vennanaise poja nimi oli Johannes, millest võis mõista, et see oligi sama mees. See kummaline väljend "vennanaise poeg" ja mitte vennapoeg tuleb ehk sellest, et vend, samuti Johannes Silberberg ${ }^{10}$ (1888-1930) oli kaua aega tagasi surnud, tema naine oli aga silmahakkav isik. Johannes Soomi tunti külas seega kui metsavenda. Ilmar Jõesoo on temast hiljem korduvalt ja pikemalt rääkinud. Mätiku kohta küsiti ka, millisena see koht varem

${ }^{10}$ Artiklis eelpool, seoses ajaloolise traditsiooni kogumisega 1924. aastal mainitud Jaan Silberberg (1849-1931) on Miina Lauriku ja Johannes Silberbergi isa. 
välja nägi või mis seal oli. Nii kuuldakse Hilda Kollolt, et Mätikul oli vanasti suitsutare. Sealt viis purre üle jõe, ent talvel liiguti jääd pidi. Seevastu Hõbeda juures (keskajast teada vesiveski koht, ametlikult Möldri), seal oli nahksild - see oli kaunis õotsuv ja ohtlik.

Loomulikult huvitusid kaevajad sellest, kas ei ole veel teateid muistsetest kalmetest, ohvrikohtadest ja muinasküladest. Kui on keegi maad kaevates sattunud sellistele esemetele või on kuuldud lugusid nt kirikumägedest - see võib viidata muistisele. Eva Popsi ema Miina kõneles sellega seoses Mätiku taga olevast Keldrimäest, kus olevat enne kirik olnud. Arheoloogid tegid sellest teatest lähtudes Keldrimäel küll proovikaevamisi, kuid kultuurkihte nad ei leidnud.

\section{Piirid ja nimemuutmised}

Maidla jääb Lääne-, Harju- ja Raplamaa piirile. 1990. aasta Maidla-külastuse ajal oli muuhulgas jutuks ka kohalike seas hiljuti läbiviidud küsitlus selle kohta, kas nad eelistavad jääda Raplamaale või liituda ajaloolise Läänemaaga. Vastustes tuli esile, et ajaloost olulisem on see, millega ollakse harjutud. Näiteks selgitas üks elanikke: See küsitlus läks sassi. Sellest ei tulnd midagi välja. Ma olin ikka Rapla poolt, kus ma põgenen (MK: Maidla 2016).

Maidlas on silmahakkavalt palju kohanimesid ja küla- või ka valla- ja maakonnapiiregi muudetud. Alustades Maidla enda nimega, mis on külarahva poolt esmalt 17.-18. sajandil kasutusele võetud mõisa nimena, tuletatuna mõisnike Maydelite nimest, ja 19. sajandi teisest poolest Kaeküla nime asemel ka külanimena (EKNR 2016, 359). Veel 1726. aastal kasutati mõisavalla nimetustena eesti keeles paralleelnimesid Maidle ehk Mäevalla.

Välitöö-vestlustest ja osalt ka arhiividokumentidest ilmnes, et talunimede muutmine tulenes pererahva soovist anda uuele elukohale oma endise elukoha nimi. Nii muutis Ilmar Jõesoo Anni talu Lutsuks, Helve Lipu nimetas oma praeguse kodutalu Laari ümber naabruses asunud lapsepõlvekodu järgi Nääguks, mis nõukogude ajal oli ilmselt venekeelsete dokumentide tõttu ka Neego, nagu oletab Helve (MK: Maidla 2016). Viimast nimekuju kohtab nii varasemates saksakeelsetes kui ka tänapäevastes dokumentides. Neego esmamainimise nimekuju on Necko aastast 1524 (TLA 230.1.Bm23, 128). Tõenäoliselt on "Näägu" kõnekeelne, sobitudes kohaliku murdega, kus "e” hääldub “ä" (nt Hermann > Ärman) ning kus järgsilpides ei 
ole "o" vaid "u" (vrd Kolovere > Koluvere). Postimäe talu peremees Aare Tarendi nimetas endise vallamaja koha 1995. aastal Ullimullaks (LVMA.532RP.3.8357). Selline kohanimede ülekandmine teisele kohale ei iseloomusta kogu piirkonda üldiselt. Nimemuutused näikse koonduvat küla nendesse osadesse, kus on tihedam asustus ja läbikäimine. Nii Lutsu kui Näägu nimede alalhoidmine, kandes nimed üle uuele kohale, seletub suguvõsa- ja pereajalooga.

Maidlas püsivamate talunimede hulgas on samuti vähemalt 16. sajandist siiani kasutusel olev Viduva. Erinevalt eelkirjeldatud Lutsust on Viduva hajatalu. Teadupärast püsisid hajatalude nimed suhteliselt stabiilseina (Liitoja-Tarkiainen 2000, 76). Ilmneb, et hajatalude nimed kinnistusid kohaga, teised nimed pigem peredega. Maidla küla on esmakordselt mainitud Läänemaa vakuraamatus 1518. aastal Toukenbeke nime all (Stackelberg 1928). Ühtlasi on vakuraamatus mainitud üht külaelanikku, seppa Widovari, kelle nimest võiks tuleneda Viduva hajatalu nimi. Viduva-Jaani oli ka esimene Maidla talu, mis päriseks saadi (ERA.3724.1.517). Maidla mõisnik kinkis selle oma mõisavalitsejale Carl Baumannile 1869. aastal (EAA.2840.1.1220). ${ }^{11}$ Tänapäeval on Viduva-nimelisi kohti lausa kaks, üks jääb Maidla küla piiridesse, teise on ametnikud üle kandnud Laukna küla piiridesse. Eelmainitud vakuraamatust leiab Maidlaga praegu seotud kohanimedest 1518. aastal olemas olnutest veel Õmma - Engema, Ullimulla - Ulimola (Stackelberg 1928, 190).

Kohanimede ja külapiiride muutumist on märkimisväärselt mõjutanud administratiivsed kaalutlused: mõisa rajamine, talurahvareformid, keskvõimu tugevdamine, nõukogude ajal ka kolhooside loomine ja Eesti jaotamine rajoonidesse. Mõisa rajas 1631. aastal Jürgen Maydel sõdadest ja taudidest tühjaks jäänud Tockumbecki (Tokunmäki, Tokumäe, Togumäe, Tagumägi) küla asemele (EAA.858.2.156). Ilmar Jõesoolt kuuldud pärimuse järgi olla toimunud ka allesjäänud Tokumäe küla talude sundasustamine soo äärde ja uue küla nimeks saanud Kaeküla (Ilmar nimetas seda Käokülaks), mis viitavat mõisamäel kaotatud külale. Arhiiviallikatest tuleb siiski välja Kaeküla nime ligi sada aastat varasem eksisteerimine (Khaykell): Kullamaa vakuraamatus 1524 . aastal ja samas raamatus 1526. aastal tehakse vahet Suurel ja Väikesel Kaekülal (Kaikel Major, Kaikel Minor, TLA.230.1. Bm23). Kahjuks ei võimalda külade

${ }^{11}$ Carl Baumann ei ole artiklis varem mainitud Karl Baumann, Ilmar Jõesoo vaarisa, tegemist on Ilmari kaugema sugulasega. 
all nimetatud, kuid tänapäevaks lokaliseerimatud talud kindlaks määrata nende kahe Kaeküla piire. 1648. aasta kohtuprotsessil mõisa poolt suletud kirikutee asjus meenutas 60-aastane Joosta Jaan, et ta on esivanematelt kuulnud, et vaidlusalusel kohal asus enne küla ja kirikutee (EAA.858.1.7146). Samal aastal on mõisal veel probleeme riigi nõuetega tagastada kaugemalasuvad hajatalud. Need jäid küll Maidla mõisale edasi, kuid Vaikna mõisale tuli ära anda Kasterma ja Läwwi hajatalu (EAA.2.2.114). Väikese ja Suure Kaeküla (ja hiljem Maidla eri piirkondade) kujunemisele aitas kaasa Maidla mõisniku poolt mõisa ja poole talumaade pantimine 1665. aastal. Pandipidajaga lepiti kokku, et piiriks jääb jõgi, kuid järgnevalt suutsid Maydelid kanda kinnitada ka teisel pool jõge ja nii rajati uus mõis ehk Pajumõis just Maidla mõisaga samale poole jõge: Väike Kaeküla kuulus Pajumõisa ja Suur Kaeküla Maidla mõisa alla. Selline lõhestatud olukord kestis terve Rootsi aja ning lõppes pärast Põhjasõda, kui Hans Ernst von Maydel (1648-1728) sai riigilt tagasi mõlemad mõisad. Pajumõisast sai siis Maidla mõisa karjamõis.

Pärisorjuse kaotamise, mõisavalla asemel talurahva juhtida olevate valdade moodustamise ja talumaade kruntimisega 19. sajandil vähenes külanimede tähendus. Mõisavalla nimetus Maidla on piirkonnal juba 18. sajandil, ent nüüd võetakse see kasutusele Kaeküla asemel. 19. sajandi keskel kadus Kaeküla nimetus ametlikest dokumentidest. See figureerib veel 1858. aasta hingeloenduses, mis oma konservatiivsuses lähtus külade ja talude nimetamisel varasematest loendustest (EAA.1864.2.X-280). Viimati võib seda nimekasutust leida Eestimaa kubermangu maamõõtja Schmidti kaardil 1871. aastast, kus see on esitatud nimekujul Kaeokül (EAA.854.4.14). Sellisest nimekujust tuleneks eestikeelne kohanimi Käoküla, kuid tegemist on siiski sageli kaartidel ette tuleva vanematelt kaartidelt ümber kirjutamisel tekkinud eksitusega. Eksimise näiteks on ka samal kaardil küla nime kõrval oleva hajatalu Näägu kirjavorm Rägo. 1866. aastal moodustati kolme küla: Maidla, SuureKalju ja Salutaguse peale ühine vallakohus. 1890. aastal ühendati Maidla vald Kalju vallaga. Koluvere ja Kalju vallale (kuhu kuulus ka Maidla küla) moodustati ühine vallakohus. Valla- ja kohtumaja jäid endiselt Maidla külla, ent need viidi 1895. aastal Tikamäelt küla lõuna serva (praeguse nimetusega Ullimulla), lähemale Koluvere valla kõige rahvarohkemale külale Lauknale. 
Maidla külamaade kruntimine toimus aastatel 1877-1887 (EAA.3724.4.660). Kruntimist kajastaval maakaardil on palju mikrotoponüüme, mille mäletamist ja lokaliseerimist oleme välitööde käigus püüdnud kontrollida. Paljud nimed on aga täielikult unustusse vajunud: Kassialt järv, Rabanuka mägi, Kotimetsa raba, Nötke soon, Kahastagune soo, Kongimets, Pammuna mägi, Päevniku koht, Konnaro mägi, Rausi sõerd jne. ${ }^{12}$

1938. aastast määrati Maidla Kullamaa valla alla ning Tõlva ja Nikre talu Maidla külast Ääsmäe-Haapsalu maantee äärest liideti Piirsalu vallaga (ERA.3922.1.192, 1 12-13). 1950. aastast asus Maidla Märjamaa rajoonis (Uuet 2002, 166). 1949. aastal moodustati külas kolm kolhoosi, mis küll järgmisel aastal ühendati. Välitööde käigus 1987-1990 õnnestus küsitleda kolme kolhooside rajamisel juhtrolli mänginud isikut: Karl Vask oli Maidla kolhoosi esimene esimees ja ka hiljem ühendkolhoosi Leek esimees, Harald Tederov oli Linda kolhoosi esimene esimees ja Linda Laanemäe Koidiku kolhoosis brigadir. Kunagised esimehed oma rolli küsitlemisel ei avanud, kuid kolhooside nimesid mäletasid küll. Kolhoosiaegsest kirjavahetusest ja ametlikest dokumentidest ilmneb, et kolhoosinimi Leek hakkas aadressides domineerima Maidla küla nime asemel. 2016. aasta välitööde ajal olid esimesed kolhoosinimed juba ununemas ning Koidiku ja Linda asukohad aeti segamini. 1958. aastal liideti kolhoos Sooniste sovhoosiga ja 1961. aastal viidi sovhoosikeskus Maidla külast Lauknale. Pärast Maidla kooli likvideerimist 1972. aastal ei jäänud külla enam midagi, mis oleks administratiivselt küla koos hoidnud. 1977. aastal ühendati Maidla ja Salutaguse ning nimetati ümber Tika külaks. 1997. aastal nimetati Tika küla Maidlaks. Tänapäeval on Maidla küla territooriumilt küll Märjamaa valla suurim, kuid elanike arvu poolest (86) on küla vallas kümnendal kohal. ${ }^{13}$ Valla kodulehe määratlusel jääb Maidla Laukna piirkonda. Oma külavanemat Maidlal pole.

Eelnev ekskurss näitab, et kohanimetraditsioon ei püsi keskkonnas, mis on aldis vastu võtma majanduslik-poliitilisi ja administratiivseid sekkumisi. Ühtlasi on tegemist ka geograafilise piiri-alaga, mis eelnevat võimendab. Samas püsib kohamälus nimesid, mida hoitakse alal kas pere- ja kodupärimuses või kohaga seotud ajaloolistes muistendites.

12 Vrd Eesti Keele Instituudi kohanimekartoteeki (EKI, Tallinn).

13 1938. aastal oli Maidlas ja Salutagusel kokku 467 elanikku(ERA.3922.1.192). 


\section{Kokkuvõte: välitööd teadusvaldkondade vahel ja teadusvaldkondade koostöös}

Välitööd tehakse mitmetes teadusvaldkondades uurimisainese kogumiseks ja (või) loomiseks. Seda mõistet - välitöö - on siinse artikli kontekstis kõige sagedamini kasutatud folkloristikas ja arheoloogias. Kõiki välitöid iseloomustab seotus üldise teadusfilosoofilise raamiga, näiteks kuidas määratletakse kultuuri või ühiskonda ja millist teadmist peetakse teaduslikuks (vt nt Lucas 2001, 120-122). Samas iseloomustab iga teadusala välitöid selle seotus oma teadusvaldkonna uurimiseesmärkide ja -küsimustega. Ilmneb ka, et erinevatel teadusaladel on oma spetsiifiline kultuuri määratlus, mis lähtub uurimisobjektist - vrd nt arheoloogi või folkloristi uurimisala. ${ }^{14}$ Ühtlasi erinevad teadusalad välitöö käigus tehtava töö iseloomu poolest. Näiteks on ajaloolise traditsiooni (või ka suulise ajaloo) uurimises, folkloristikas ja etnoloogias tüüpilisemad uurimisandmete loomisviisid küsitlemine, intervjueerimine, aga ka vaatlus; arheoloogias seevastu esemete väljakaevamine ja leiukeskkonna dokumenteerimine. Välitöö eesmärkidest lähtuvalt on ajaloolise traditsiooni küsitlejate fookuses faktiteave, folkloristid pööravad aga enam tähelepanu loo esitusele. Erinev on ka välitööde tulem, näiteks tekstikogude, heli- ja videoarhiivide loomine folkloristikas või ajaloolise traditsiooni ja suulise ajaloo alal, arheoloogias aga esemete maapõuest väljapuhastamine ja leiukeskkonna teaduslik kirjeldamine. Kui folkloristlike, etnoloogiliste jms välitööde puhul kõneldakse teatud kultuuriilmingute säilitamisest, talletamisest vms loovast tegevusest, siis arheoloogias rõhutatakse, et välitööde käigus see kultuurikiht lõhutakse - väljakaevatavat ala ei ole võimalik enam sellisena taastada (vt nt Steinberg 2005, 77, 84).

\footnotetext{
${ }^{14}$ Marleen Metslaid on oma uurimuses etnoloog Gustav Ränga välitöödest näidanud, kuidas isegi üks ja sama uurija võib samaaegselt lähtuda kultuuri erinevatest käsitlustest: "Analüüsitud materjali põhjal võib väita, et Ränga kultuurimõistmine oli kahetine. Kogumismatkadel, eriti Karja kihelkonna rahvariiete kohta andmeid kogudes on ta lähtunud juba Kr. Raua ajast pärinevast rahvakunstist ja "arenenud ilumeelega talupojast" [---]. Kalastust uurides Ränga kultuuripiirid justkui laienevad, ta vaatleb rahvakultuuri praktilisemat poolt, kus eseme vanuse ja "rahvaesinduslikkuse" asemel on esikohal selle funktsioon" (Nõmmela 2007, 157).
} 
20. sajandi viimasest veerandist on üha enam esil interdistsiplinaarsus. Kuidas interdistsiplinaarsus muudab arusaama välitööst? Kuidas see avaldub siin artiklis käsitletavas? Sellele küsimusele saab suuremas osas vastata tagasivaatavalt, sest 1980. aastate lõpul ja 1990. aastal, välitööde tegemise ajal, oli teadusvaldkondade-vahelisus teoreetiliselt sõnastamata püüdlus. Rahvusvaheliselt tuleb folkloristlike välitööde kujunemisega seoses enam esile kultuuri- või sotsiaalantropoloogia ja sotsioloogia, kuid mitte arheoloogia või ajaloo uurimine. See on täiesti erinev olukord, võrreldes teadusalade väljakujunemise ajajärguga (Eestis) 19. sajandi lõpul, 20. sajandi alguses. Meenutatagu näiteks muinasteaduse mõistet ja Jaan Jungi koostatud tekste ("Muinasteadus eestlaste maalt") - muinasteadus hõlmas nii muistendeid kui ka muistiseid. Kuigi arheoloogiliselt huvipakkuvate alade leidmisel on jätkuvalt kasutatud pärimusteadmisi, võiks küsida miks interdistsiplinaarsel ajajärgul 20. sajandi lõpul ja 21. sajandi alguses on folkloristika märkimisväärselt seotud hoopis sotsioloogia või antropoloogiaga?

Siin tuleb arvesse kaks folkloristikat mõjutanud aspekti. Kui 20. sajandi esimesel poolel oli uurimiskese minevikul (nn vana, modernismieelne talupojakultuur) ja tekstidel, siis 20. sajandi teisel poolel süvenes üha enam huvi pärimusrühma ja selle liikmete ja ühtlasi tänapäeva folkloori vastu. ${ }^{15}$ Need muutused kergitasid esile pärimuskeskkonna sotsiaalsed ja kommunikatiivsed aspektid. Kõnesoleva välitöö kontekstis haakub nende suundumustega kirjeldatud põlvkondlike kontekstide jälgimine: kes, mis asjaoludel, kellele neid või teisi asju kõneles; kuidas või millega seoses neid või teisi lugusid teatakse. Viie naise küsitlus-aruandes on pidevalt nähtavad viited ka tekstide vahendamisele. Näiteks:

Koluvere krahv sõitnud nii hirmsasti, et kabjad tulid hobusel alt ära.

Isa rä̈̈̈kis nii, et kui siit Vaiknast läbi sai, olid hobusel kabjad alt ära. (EKRK I 90, 204 (28), 1912. a s naine)

Seda lugu (nagu teisigi nn Koluvere hullu krahvi lugusid) on vanaemalt kuulnud ka 1929. aastal sündinud naine. Teisi lugusid ta ei mäleta, sest vanaema küll rääkis, aga lapse asi on ikka lapse asi. Kuulad selle ära ja sinnapaika see jääb (EKRK I 90, 218 (7)). Kummati just seda kapjade äratulemise lugu ta teab. Aga kui palju selles tõtt on või valet, seda ma küll ei tea, kinnitab ta samas.

${ }^{15} \mathrm{Vt}$ nt ülevaadet folkloristliku teooria kujunemisest 20. sajandil ja rahvaluule defineerimise suundumustest 21. sajandi alguses (Bronner 2016). 
Ilmselt on lugude mäletamise seisukohast oluline nii lugude aktuaalsus kui ka funktsioon. Nii on (klassikalised) pärimustekstid mõneti ka eluloolised või perepärimuslikud tekstid, kus meenutamise ajend (Tulving 1994, 68) mängib märkimisväärset rolli (nt isa rääkis nii, vanaema küll rääkis, aga ...).

Arheoloogilistel kaevamistel osalenute huvi võib aga seostada Akadeemilise Ajaloo Seltsi või ka 1905. aasta Seltsi tegevusega enne Teist maailmasõda. Külaelanike või sündmuses osalenute mälestusi küsiti ja pandi kirja minevikusündmuste ja -olukordade selgitamiseks. Tähelepanu keskmes oli kirjalike ajalooallikate ja mälestustes alal olevate andmete omavaheline kokkuviimine, et pilt minevikust muutuks selgemaks ja faktitihedamaks.

Maidla välitööde võrdlevas näites ilmnevad teadusalade vahelise koostöö võimalused. Ühest küljest oli võimalik käsitleda enam teemasid (küla või pere ajalugu, argielu, kohanime-ajalood), teisalt oli sellest võimalik esile tuua rohkem aspekte, seostades näiteks emotsionaalsed, jutustajatest lähtuvad sõnumid dokumentides leitavate faktidega. Tuli taas esile, et pärimuse kirjapanemisel kuuldu põhjal talletatud faktiandmed ei pruugi olla täpsed. Nii on ajaloolise traditsiooni kogus kasutatud nimekuju "Kaarel Bauman", kes on Karl Baumann; 1990. aasta rahvaluulekogus ei vasta tegelikkusele üks talunimi: Allika talu on õieti Haaviku, ja üks eesnimi Ida (Kollo), mis on tegelikult Hilda (EKRK I 90, 207, 230).

Kui 19. sajandil ja suures osas ka 20. sajandil oli tavaline, et materjali kogumine välitöödel on ettevalmistav etapp uurimiseks või näiteks tekstide publitseerimiseks (ajaloolaste töödes - materjali kogumine lünkade täitmiseks, kui klassikalisi, s.o kirjalikke dokumente ei ole piisavalt), siis 20 . sajandi viimasel veerandil hakati välitöödel talletatavat üha enam seostama konkreetsete uurimisküsimustega (vrd Korb 2005, 111-112). Marleen Nõmmela (Metslaid) toob etnoloogiliste välitööde muutumise kontekstis esile nimelt välitöö protsessilise loomuse, kus uurija saab pidevalt tagasi minna uuritavasse kogukonda, esitades jätkuvalt küsimusi (Nõmmela 2007, 15-16). Anu Korb aga kahtleb põhjendatult, kas uurijahuvist lähtuv välitöö ei tekita olukorda, kus materjale arhiivitekstiks ei vormistata ja ühtlasi ei anta neid kesksesse arhiivi, kus seda materjali saaksid kasutada kõik huvilised? Siin käsitletud ainesest on rahvaluulearhiivis vaid üks väike osa, see, mis puudutab rahvaluulepraktikat 1990. aastal (EKRK I 90). Võib küsida, kas järjepidevalt täienev 
Maidla-mapp (MK: Maidla; MK: Läänemaa), sh Maidla kohalike elanike küsitlused 1995., 2003. ja 2016. aastal on käsitletavad välitööna või mitte? Ühelt poolt pakkusid needki informatsiooni üldisema uurimishuvi vaatepunktist, ent organisatsiooniliselt olid need juhukäigud, toimunud spontaanselt, puhkuse ajal, vormistatuna peamiselt mustandmärkmetena. Kas arhiivis avalikult kättesaadav materjal on eesmärk omaette, kui aines on kogutud ühe või mõne uurija tööhuvidest lähtuvalt? Ilmselt on see arutelu koht. Siinse artikli kontekstis tõstatub aga näiteks küsimus, kuidas paigutada avalikust arhiivist (ajalooarhiiv) väljaotsitud andmed ja nendega seostatud välitöödelt kogutud andmed ühtsesse avalikult kättesaadavasse välitöömaterjalide arhiivi (ehk kust algab ja lõpeb uurimine ning andmete kõigile vabalt kättesaadavus). Üldisemalt haakub see küsimus kvalitatiivsete meetodite eripäraga, kus uurija asetub ka ise uuritavasse maailma ja kus välitöö hõlmab geograafilise ruumi kõrval ka uurija tegevust, mis toimub välitöö-paigast eemal. Nii muutub välitöö mitmetasandiliseks protsessiks, mistõttu on vältimatu välitöö avalikustamine uurimuse, mitte materjalikoguna.

\section{Lõpetuseks}

Välitööd seostuvad sageli kontaktisiku või vahendajaga, kes võib olla nii teejuht kui info jagaja. Kohati võib ta uurijat ka häirida, surudes peale oma seisukohti, eelarvamusi vms. Ja on vahendajaid, kelle abil kohaliku kultuuri sügavamatesse kihtidesse ligi pääsetakse. Nii või teisti - välitöö-aruannetes mainitakse kontaktisikuid harva. Ilmar Jõesoo täitis vahendaja rolli nii arheoloogide, ajaloolaste kui folkloristide jaoks. Ta oli laialdaste teadmistega mitmekülgne isiksus. Temaga seoses saab rääkida pigem koostööst kui pelgalt kontakte loovast vahendajast. Tema soov oli oma teadmisi edasi anda, leida võimalikult palju neid, kes said ühel või teisel viisil tema tõukest edasi minna.

Kogus "Ajaloolist traditsiooni" on mainitud, et Ilmari vaarisa Karl oli jutukas ja üleskirjutustest võib näha positiivset ellusuhtumist (hoolimata kehvast toidust olid inimesed ikka prisked ja rõomsad). Sama võib ära tunda ka Ilmarist. 


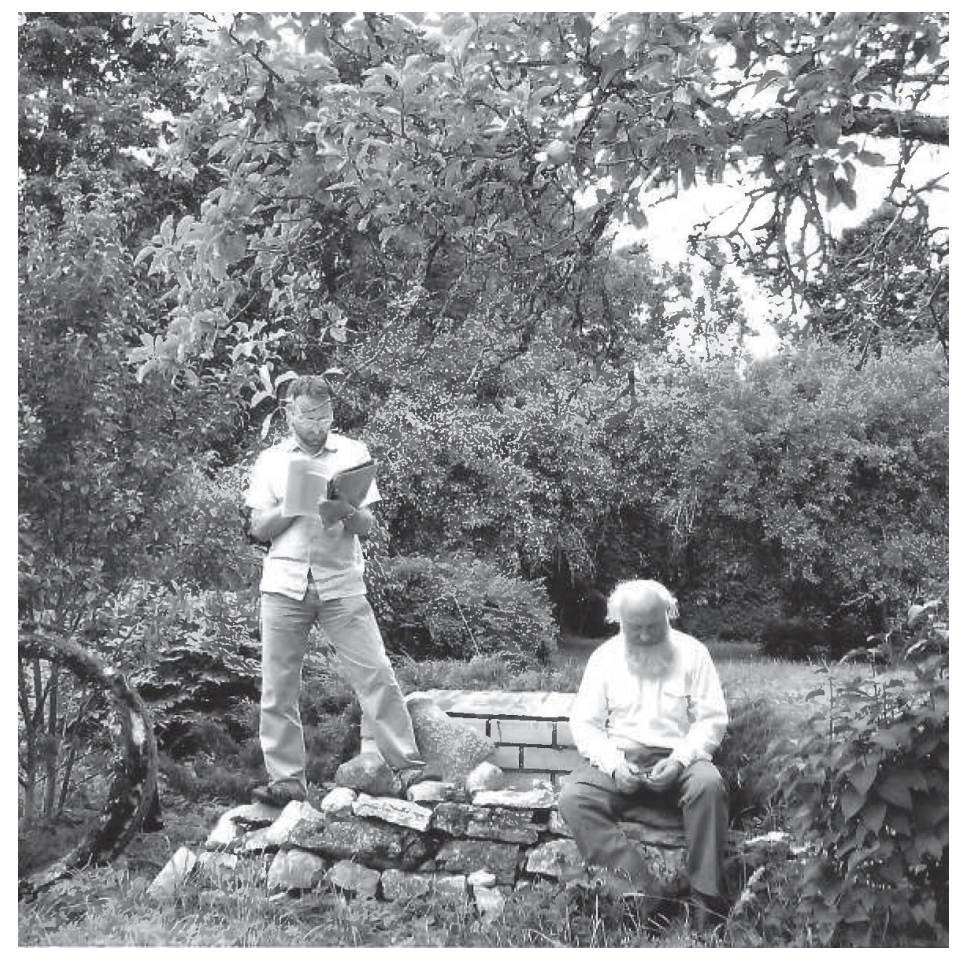

Kalev Jaago ja Ilmar Jõesoo Hubergide suguvõsa kokkutulekul 2006. Foto erakogust.

Artikkel on seotud Haridus- ja Teadusministeeriumi uurimisprojektiga IUT 2-43 "Traditsioon, loovus ja ühiskond" ning Soome TA projektiga "Traumatized borders" (SA 297533). Versioon artiklist on ilmunud Lä̈̈nemaa Muuseumi toimetistes XXI, 2018.

\section{Allikad}

Eesti Keele Instituudi kohanimekartoteek - Eesti Keele Instituut, Tallinn. EKLA f 200 - Eesti Kirjanduse Seltsi stipendiaatide kogu: Ajaloolist traditsiooni, Eesti Kirjandusmuuseumi kultuurilooline arhiiv.

EKRK I 90 - Eesti kirjanduse ja rahvaluule kateedri rahvaluule-kogu, Läänemaa 1990, Eesti Kirjandusmuuseumi rahvaluule arhiiv. 


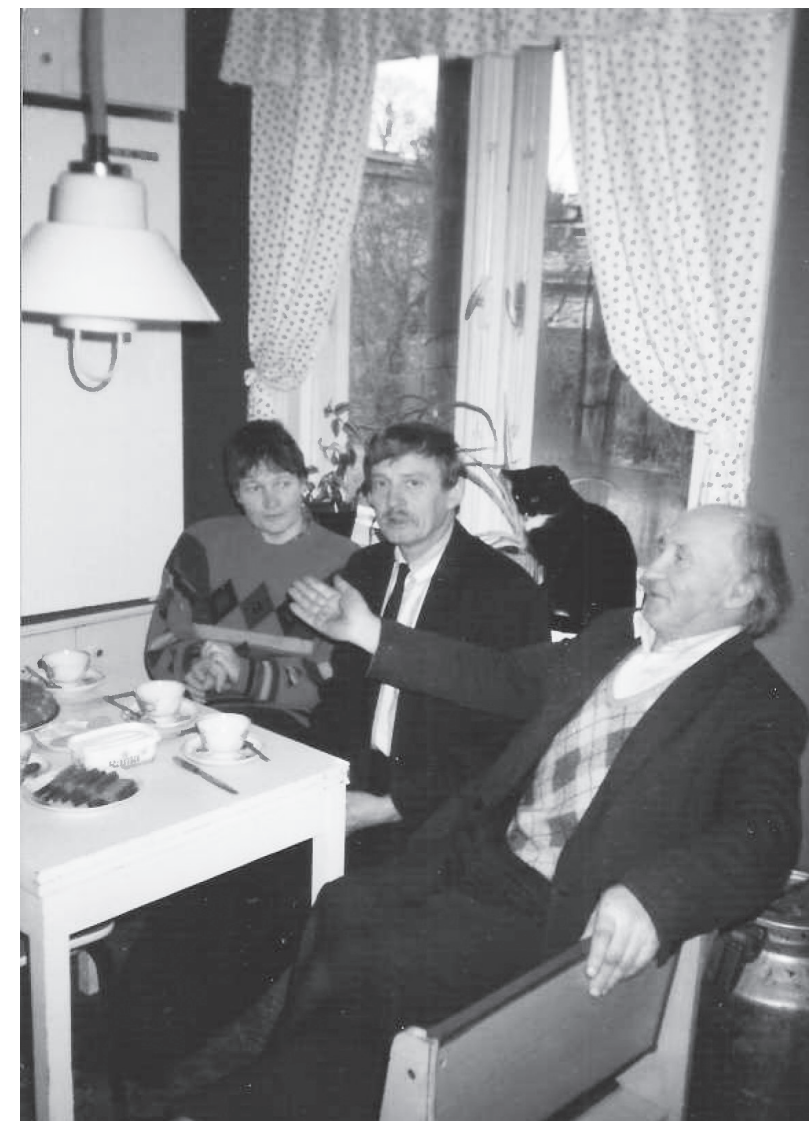

Larissa ja Mati Mandel ning Ilmar Jõesoo juttu ajamas Ilmari kodus Haapsalus 1990. aastate alguses. Foto erakogust.

elk.88.0.10 - Kullamaa kiriku matusteraamat. Käsikiri Kullamaal kiriku koguduse arhiivis.

MK: Läänemaa - Läänemaalt kogutud pärimusliku ajaloo materjalide kogu Tartu Ülikooli eesti ja võrdleva rahvaluule osakonnas (perepärimusteemaline vestlus Ainu Tikenbergiga Ristil, 27. juulil 2009. Helifail; eluloo-intervjuu Ilmar Jõesooga Haapsalus, 26. jaanuaril 2012. Helifail). MK: Maidla - Maidlat puudutavad materjalid (1986-2016) Kalev Jaago erakogus. 
EAA; ERA; LVMA - Rahvusarhiiv:

EAA.2 - Tallinna Linnusekohus;

EAA.858 - Eestimaa Ülemmaakohus;

EAA.1243 - EELK Kullamaa kogudus;

EAA.1864 - Eestimaa kubermangu revisjonilehtede kollektsioon;

EAA.3724 - Katastridokumentide kollektsioon;

EAA.2840 - Tallinna Kinnistusamet;

ERA.3724 - Põllutööministeeriumi Katastri Amet;

ERA.3922 - Kolovere-Kalju vallavalitsus;

LVMA.532RP - Rapla Maakonna hooneregister.

SRA - Rootsi Riigiarhiiv, Baltiska Fögdensräkenskaper 387, 1568-1570.

TLA - Tallinna Linnaarhiiv, TLA.230.1.Bm23 - Kullamaa vakuraamat.

\section{Kirjandus}

Aarma, Liivi 2014. Kullamaa kihelkonna ajaraamat. Esmamainimisest 20. sajandini. Kullamaa: OÜ Vali Press.

APK $1988=$ Ajaloopärimuse küsimustik. 1988. Tallinn: Eesti Muinsuskaitse Seltsi ajalootoimkond.

Ben-Amos, Dan 1981. Zu einer Definition der Folklore im Kontext. - Dow, James R. \& Lixfeld, Hannjost (koost). Jahrbuch für Volksliedforschung 26. Jg. Berliin: Schmidt, 15-30 (doi: 10.2307/847811).

Bronner, Simon J. 2016. Toward a Definition of Folklore in Practice. - Cultural Analysis 15 (1), 6-27 (https://pdfs.semanticscholar.org/2429/ f8f05df53b9c80941bf0ea50923436704160.pdf - 16.02.2018).

EKNR 2016 = Kallasmaa, Marja \& Saar, Evar \& Päll, Peeter \& Joalaid, Marje \& Kiristaja, Arvis \& Ernits, Enn \& Faster, Marika \& Puss, Fred \& Laansalu, Tiina \& Paales, Liina (koost) 2016. Eesti kohanimeraamat. Tallinn: Eesti Keele Sihtasutus.

Hiiemäe, Mall 1978. Kodavere pajatused. Kujunemine ja koht rahvajututraditsioonis. Tallinn: Eesti Raamat.

Hiiemäe, Mall 1985. Eesti rahvakalender IV. Tallinn: Eesti Raamat. Jaago, Tiiu 1999. Rahvaluule mõiste kujunemine Eestis. - Mäetagused 9, 70-91 (doi:10.7592/MT1999.09.rhl).

Jaago, Tiiu 2005. Pärimuslik ajalugu ja Kreutzwald. - ÕES aastaraamat 2003. Tartu: Tartu Ülikooli Kirjastus, 9-20.

Jaago, Tiiu 2009a. Valge hobuse kivi lugu. Üdrumal 22. veebruaril 1918. aastal toimunud lahing pärimusliku ajaloo vaatevinklist. - Paras, Ülla (toim). Läänemaa Muuseumi toimetised XII. Haapsalu: Läänemaa Muuseum, 116-144. 
Jaago, Tiiu 2009b. Lugu ja sündmus jutu-uurimises: situatsioonianalüüsist kontekstianalüüsini. - Mäetagused 43, 125-144 (doi:10.7592/MT2009.43. jaago).

Kant, Edgar 2007. Eesti rahvastik ja asustus. Tartu: Ilmamaa.

Korb, Anu 2005. Venemaal rahvuskaaslasi küsitlemas: folkloristliku välitöö metoodilisi aspekte. Studia Ethnologica et Folkloristica Tartuensia 9. Tartu: Tartu Ülikooli Kirjastus.

Laagus, Aino 1973. Situatsioonianalüüsist folkloristikas. - Keel ja Kirjandus 7, 404-412 = Laagus, Aino 2009. Mäetagused 43, 113-124 (doi:10.7592/MT2009.43.laagus).

Laanemäe, Aare 2012. Kesknõmme - külakultuuri fenomen. - Tarang, Lembitu (koost). Kullamaa mälestused. Kullamaa: Kullamaa Kihelkonna Muusuem, 72-79.

Liitoja-Tarkiainen, Ülle 2000. Hajatalud ja külad Põhja-Liivimaal 17. sajandil. Tartu: Eesti Ajalooarhiiv.

Läänemaa 1938 = Habermann, Harald (peatoim). Läänemaa. Maateaduslik, majanduslik ja ajalooline kirjeldus. Üldosa. Tartu: Eesti Kirjanduse Selts.

Lucas, Gavin 2001. Critical Approaches to Fieldwork: Contemporary and Historical Archaeological Practice. London, New York: Routledge.

Mandel, Mati 2017. Maidla muinaskalmistu saladused. Tallinn: Eesti ajaloomuuseum.

Nõmmela, Marleen 2007. Etnograafiks kujunemine: Gustav Ränga välitööpraktika 1920. aastatel. Studia Ethnologica et Folkloristica Tartuensia 10. Tartu: Tartu Ülikooli Kirjastus.

Pärdi, Heiki 1998. Karjakasvatus. - Viires, Ants \&Vunder, Elle (toim). Eesti rahvakultuur. Tallinn: Eesti Entsüklopeediakirjastus, 100-117.

Sarv, Vaike 2000. Setu itkukultuur. Ars Musicae Popularis 14. Tartu, Tampere: Eesti Kirjandusmuuseum, etnomusikoloogia osakond, Tampereen yliopiston kansanperinteen laitos.

Stackelberg, Friedrich 1928. Das älteste Wackenbuch der Wiek. - Õpetatud Eesti Seltsi aastaraamat 1927. Tartu: K. Mattieseni trükk, 78-254.

Steinberg, John M. 2005. Logistics of Fieldwork and Collecting Field Data. Maschner, Herbert D. G. \& Chippindale, Christopher (toim). Handbook of Archaeological Methods. Lanham, Maryland: AltaMiraPress, 75-105.

Tedre, Ülo 2003 [1954]. Eesti mees ja tema sugu. XIX sajandi Eesti lõppriimilises rahvalaulus. Tallinn - Tartu: Eesti Kirjandusmuuseum.

Tulving, Endel 1994. Mälu. Tallinn: Kupar.

Uuet, Liivi 2002. Eesti haldusjaotus 20. sajandil. Tallinn: Eesti Omavalitsusliitude Ühendus, Riigiarhiiv. 


\section{Summary}

\section{Fieldwork: Maidla case study}

Keywords: "era of the Republic of Estonia", fieldwork, Ilmar Jõesoo, local and family history, Maidla

The article examines the development of fieldwork as a data collection method at the end of the 20th century. Fieldwork became increasingly more prominent in interdisciplinary and qualitative research at that time. Fieldwork performed since 1987 in a region bordering two counties is used as an example to discuss why the locals were questioned (the purpose) and the manner in which gathered information was documented.

The discussion revolves around three sets of questions. First: Humanity scholars began to express increasingly more interest in the pre-Soviet period in Estonia during the second half of the 1980s (i.e. towards the end of the Soviet era). Since the official and popular treatments of history were contradictory, historians initiated a campaign to collect the memories of elderly people. This also served as the starting point of students and historians present at the archaeological excavations in Maidla. The purpose of questioning locals was to learn more about contemporary history (topics such as the period of the Republic of Estonia, the war, the forest brothers, mass deportations, etc. that were suppressed during the Soviet era). In writing down the surveys, attention was given to events, names and other facts. The materials remained in private ownership and have been complemented consistently.

Second: folklorist theory was updated during this period, allowing for more consideration to be given to lore of the recent past. It is even more important that in addition to different types of folklore, research focus now also started to make room for social groups and the context in which lore was performed. Folklore fieldwork material is stored in the Estonian Folklore Archives.

Third: it is important to keep in mind that this period saw the rise of interdisciplinary research. A shared interest in the recent past connects the study of history and folkloristics at the end of the 20th century. This is partially caused by the shift from subject-based study to the study of performers and the environment of performance in folkloristics. Analysis carried out by historians and folklorists of the fieldwork material includes local traditions and the social and generational background of the distribution of such traditions. This is complemented with work in archives where historical documents can be used to follow the evolution of local settlements and toponymy all the way from the 16 th century to today. 


\section{PILDI SISSE MINEK. Artikleid välitööde alalt}

\section{Koostanud ja toimetanud EDA KALMRE}

http://www.folklore.ee/rl/pubte/ee/cf/pildisisse

ISBN 978-9949-586-93-6

DOI $10.7592 / \mathrm{TF} 11$

Tartu 2019

Trükis ilmunud:

Pildi sisse minek. Artikleid välitööde alalt.

Tänapäeva folkloorist 11. Tartu 2019

Sarja peatoimetaja: Eda Kalmre

Kogumiku koostaja ja toimetaja: Eda Kalmre

Keeletoimetaja: Asta Niinemets

Kaanekujundus: Artur Kuus

Küljendus: Diana Kahre

Veebiväljaanne: Diana Kahre

Trükitud Eesti Kultuurkapitali toetusel. Väljaande valmimine on seotud Euroopa Liidu Euroopa Regionaalarengu Fondi (Eesti-uuringute Tippkeskus) ja Eesti Haridus- ja Teadusministeeriumi uurimisprojektiga IUT 22-5. Väljaande valmimist on toetanud Akadeemiline Rahvaluule Selts.

E-raamatu valmimist toetas: EKKM14-344 Eesti keele, kultuuri ja folkloori kasutusalade laiendamine ja tutvustamine elektroonilistel infokandjatel.

(C) Eesti Kirjandusmuuseum 2019

(C) Eda Kalmre ja autorid

(C) Artur Kuus 